\title{
O PENSAMENTO ANTROPOLÓXICO DE MANUEL M. MURGUIIA. RAZA E CULTURA
}

\author{
Por \\ FERNANDO PEREIRA GONZÁLEZ
}

\section{INTRODUCCIÓN}

Manuel Martínez Murguía foi un dos personaxes máis senlleiros da cultura galega durante a segunda metade do século XIX e as dúas primeiras décadas do presente. Chamado, con xustiza, ó final da súa longa vida «O Patriarca», a súa obra e as súas actividades vitais abranxeron múltiples aspectos, en moitos dos cales deixou unha importante pegada: escritor, xornalista, arquiveiro e bibliotecario, historiador, estudioso da cultura popular galega, afeccionado á arqueoloxía, crítico literario, político, animador cultural... A súa producción intelectual, pois, caracterízase non só pola súa dimensión cuantitativa, senón, e sobre todo, pola súa grande trascendencia cualitativa que amosou de cara ó porvir (Velasco Souto, 1998: 23).

Por salientar só dous ámbitos nos que a súa influencia se demostrou especialmente importante e duradeira, foi Murguía -como ten demostrado Ramón Máiz- o primeiro teorizador da nacionalidade galega, da súa fundamentación e da súa xustificación; teorización que en esencia sería recollida posteriormente polo nacionalismo galego no século actual.Ademais, como historiador, a súa visión da historia de Galicia en boa parte segue a estar presente hoxe en día e, para ben ou para mal, continúa influenciando a maneira en como os galegos e as galegas concibimos o noso pasado.

"CUADERNOS DE ESTUDIOS GALLEGOS", Tomo XLVII, Fascículo 113, Santiago 2000. 
Xa que logo a importancia de Murguía na cultura e na política da historia recente do noso país está fóra de toda dúbida. Paradoxalmente, e a pesar do xeral recoñecemento desta importancia, a vida e maila obra deste autor aínda non están suficientemente estudiadas, cando menos non o están todas as súas múltiples facetas. Malia a existiren algunhas achegas biográficas de carácter máis ben breve (Risco, 1976; Beramendi, 1982 e 1998), bótase en falta un estudio amplo da súa vida, da súa obra, da súa personalidade e do seu pensamento. Namentres non se conte cun traballo semellante debémonos conformar cunha serie de estudios parciais que poidan botar algunhas luces sobre o extenso do labor e da obra murguiáns. Entre estes estudios destaca, sen dúbida, o de Ramón Máiz sobre o Rexionalismo galego (Máiz, 1984), no que se inclúe unha magnífica análise acerca da actividade e do pensamento políticos de Murguía. Tamén son importantes os estudios consagrados á súa producción histórica (Mato Domínguez, 1981; Máiz, 1997; Velasco Souto, 1998). A estes traballos hai que engadir diversas achegas a respecto doutros aspectos da actividade de Murguía: crítica literaria, estudio da cultura popular galega, pensamento arqueolóxico, etc.

O presente artigo pretende ser outra achega máis ó estudio deste autor nado en Oseiro (Arteixo-A Coruña) en 1833, centrada esta vez nun aspecto pouco tratado da súa vasta producción intelectual: o seu pensamento antropolóxico, é dicir nas súas reflexións sobre a orixe e natureza do ser humano, o concepto de cultura e a diversidade humana. Murguía, como home do seu tempo, non podía ficar a parte das correntes de investigación e de pensamento que lle eran contemporáneas, nunha época na que as devanditas cuestións antropolóxicas cobraran unha grande importancia a raíz dos desenvolvementos experimentados pola ciencia e o pensamento occidentais dende finais do século XVIII (evolucionismo, superación do marco bíblico de referencia á hora de facer historia, recoñecemento da grande antigüidade da humanidade, teorías sobre a raza...). Como se verá ó longo deste artigo, en repetidas ocasións fará referencia Murguía a estes e a outros temas antropolóxicos, reflectindo así o impacto que as distintas teorías e orientacións da nacente antropoloxía europea tiveron no seu pensamento.

Con todo cómpre afirmar xa dende un principio que seu o pensamento antropolóxico non foi, nin moito menos, unha reflexión sistemática e artellada. As cuestións antropolóxicas arriba citadas non foron o principal

"CUADERNOS DE ESTUdIOS GALLEGOS", Tomo XLVII, Fascículo 113, Santiago 2000. 
interese do labor investigador de Murguía. Toda a súa traxectoria vital e intelectual estivo marcada pola súa preocupación por Galicia, e moi especialmente polo estudio e divulgación da súa historia, da súa arte, da súa literatura e folklore; e isto non só por un interese simplemente "erudito», senón co claro obxectivo de demostrar o «feito diferencial galego», e posteriormente de teorizar a nación galega (a súa orixe, a súa presencia durante a historia, o estado presente, as súas bases), como requisito indispensable para reivindicar os seus dereitos a unha existencia autónoma e a ser dona do seu destino. E para iso era necesario dotar ó país dunha historia e dunha literatura propias, dunha identidade e dunha conciencia de seu...

Este «lugar central» que na súa obra ocupou Galicia impoñía o marco de referencia esencial do seu pensamento antropolóxico. Neste sentido, aquela temática antropolóxica que ficaba fóra dos seus intereses inmediatos aparecía nos seus escritos de xeito moi tanxencial, en ocasións a penas como simples referencias. Pola contra outras cuestións antropolóxicas -nomeadamente a da raza-si que terían unha meirande presencia no seu pensamento; precisamente eran aquelas que lle servían para levar adiante ese obxectivo da súa vida. Veremos o tratamento destes e doutros temas no decurso deste traballo.

Elexín centrarme en dúas cuestións concretas: raza e cultura.

De xulgar polas múltiples referencias á raza que se atopan na súa obra, habería que concluir que a cuestión racial era de primeira importancia para Murguía, que a raza era para el o principal trazo que caracterizaba os grupos humanos e o factor que determinaba as súas accións e o seu lugar na sociedade humana (e máis concretamente no novo sistema capitalista industrial e colonial). De feito o factor racial constituía un dos principais elementos da súa definición da nacionalidade galega: era a pertenza a unha raza «celto-ariana» o que conformaba a esencia da identidade galega, o que determinaba o seu carácter e o que explicaba as súas virtudes, e o que, ata certo punto, explicaba os comportamentos, as crenzas, o idioma e incluso a organización social e as institucións peculiares do pobo galego. Nisto seguía Murguía as tendencias do momento, que apuntaban cara a unha crecente «racialización» do pensamento e das actitudes de Occidente cara a outros pobos e cara a si propio.

"CUADERNOS DE ESTUdios GALLEGOS", Tomo XLVII, Fascículo 113, Santiago 2000. 
Por isto mesmo, pola importancia que a raza tiña na obra de Murguía e no pensamento da época, é polo que a cuestión racial aparece como o obxectivo principal da miña análise verbo do seu pensamento antropolóxico.

Verbo disto contamos xa dende hai tempo coa importante análise que Ramón Máiz fixo do papel que o factor racial xogaba no ideario político de Murguía, na cal salientaba o lugar e a funcionalidade que este ocupaba na súa teorización nacionalitaria. Este estudio pioneiro sirviu como base indispensable para o presente traballo (por máis que algunhas das conclusións de Máiz precisen ser matizadas). Porén, a orientación do meu artigo non pasa tanto por considerar a funcionalidade política que o factor da raza tiña para Murguía, senón que se centra en pescudar na súa idea de raza e en pór en relación esta coas correntes de pensamento contemporáneas.

Tamén é isto o que pretendo en relación ó outro tema -a cultura-que agora me ocupa: determinar o que entendía Murguía por «cultura»; pescudar as súas opinións sobre a orixe e o desenvolvemento da civilización ou sobre a diversidade cultural; indagar cal era o lugar que no seu pensamento ocupaban os fenómenos culturais e as relacións que estes gardaban con outras compoñentes do pensamento murguián, como por exemplo o factor racial; en fin, procurar comprender o tratamento que Murguía daba ás manifestacións culturais á luz das opinións antropolóxicas do momento.

$\mathrm{O}$ concepto de «cultura» é hoxe en día un concepto fundamental dentro da reflexión antropolóxica, e na época na que escribía Murguía estaba a ser artellado o concepto moderno ou actual de «cultura antropolóxica» (Stocking, 1968). Sabendo que entendía Murguía por «cultura» será posible coñecer ademais as correntes de pensamento das que era debedor. $\mathrm{E}$ todo isto, tendo en conta outros aspectos do seu pensamento, nos levará a preguntarnos o por que das opcións por el elexidas, e a procurar explicacións posibles.

Este traballo está artellado en dous grandes apartados -dedicados respectivamente á raza e á cultura no pensamento murguián-, divididos á súa vez en varios sub-apartados que me ofrecerán a posibilidade de tratar máis libremente os distintos aspectos e implicacións dos dous conceptos estudiados.

Nin que dicir ten que os termos e os calificativos aquí empregados -«raza», «superior», «inferior», «civilizado», «salvaxe», «primitivo», etc.corresponden ó vocabulario de Murguía e da súa época, e non reflicten en absoluto o pensamento do autor deste artigo.

"CUADERNOS DE ESTUDIOS GALLEGOS", Tomo XLVII, Fascículo 113, Santiago 2000. 


\section{RAZA}

1. Antecedentes: W. F. Edwards e as teorías raciais na primeira metade do século XIX.

En 1829 o médico e antropólogo francés William Friederick Edwards (futuro fundador, en 1839, da Société Ethnologique de Paris -e a quen Claude Blanckaert ten considerado como o iniciador dunha auténtica «ciencia das razas»; cf. Blanckaert, 1988) publicaba a súa obra Des caractères physiologiques des races humaines considérés dans leurs rapports avec l'histoire. Concibido como unha carta dirixida ó historiadorAmédée Thierry, este traballo estaba destinado a servir de apoio e de confirmación das teses deste autor acerca da composición racial da nación francesa.

Se ben no intre da publicación do libro de Edwards a polémica sobre a composición étnica do pobo francés, que enfrontaba dende o século XVI ós autores partidarios de salientar a orixe galo-celta do mesmo cos escritores pro-francos ${ }^{1}$, xa estaba bastante devecida e a Revolución Francesa tiña rematado co entramado das xerarquías sociais doAntigo Réxime que pretendían defender os segundos co seu mito da conquista dos francos, os irmáns Agustin e Amédée Thierry (actuando como defensores dos dereitos da crecente burguesía fronte ós pretendidos privilexios raciais da esmorecente aristocracia) tomaban decidido partido polos primeiros e salientaban a orixe gala da grande maioría do pobo francés -o terceiro estado. Eles ademais falaban da continua loita racial que opuxera todo ó longo da historia francesa ós indíxenas galos contra os invasores xermanos; loita que se traducía nun enfrontamento histórico-político na defensa das liberdades entre a burguesía e o pobo, dun bando, e a nobreza, do outro (Poliakov, 1971; Foucault, 1992; Dietler, 1994).

No seu libro Histoire des Gaulois (1828) Amédée Thierry falaba da continuidade do «xenio galo» ó longo da historia, «xenio» encarnado e sempre presente nas clases populares francesas. Pero se Amédée e Au-

\footnotetext{
${ }^{1}$ Polémica que se coñecía na historiografía da época coa denominación de «querela das dúas razas» e que tiña unha fasquía marcadamente política, ó ser apoiada a primeira tese polos partidarios do «terceiro estado»-pobo e burguesía, que se supoñían directos descendentes dos galos romanizados; e a segunda polos defensores dos privilexios da nobreza- considerada esta por unha longa tradición historiográfica como a herdeira das xentes xermánicas que se impuxeran sobre os galos indíxenas ó crearen o reino dos francos.
} 
gustin falaban xa de «razas» -gala, xermana, francesa-e da permanencia do «xenio» galo no pobo francés, os seus argumentos a prol dunha orixe gala para a poboación francesa estiveron limitados á historia e á lingüística, sen faceren uso da «ciencia racial» que se estaba a desenvolver por entón. E ese foi, precisamente, o obxectivo da «carta» que Edwards escribiu a Amédée Thierry: establecer sobre bases máis seguras e «científicas», é dicir, sobre bases racio-biolóxicas, a orixe celta (gala e címbrica, seguindo a distinción que pouco antes establecera Amédée Thierry entre os habitantes celtas da Galia) do pobo francés (Blanckaert, 1988).

Se para os irmáns Thierry o termo raza tiña un significado eminentemente histórico, lingüístico e cultural -sen claras connotacións biolóxicas-, Edwards (máis acorde coa súa formación como médico) deulle o sentido fundamentalmente biolóxico que o termo viñera acadando dende o século anterior: unha raza era un grupo humano definido pola posesión duns trazos físicos particulares, ademais de posuir unhas características psicolóxicas e intelectuais determinadas (que as máis das veces se poñían en relación -se non se facían derivar directamente- cos primeiros). Dende finais do século XVII foron moitos os autores que se esforzaron por dividir a humanidade en razas, cada unha delas definida física, mental e culturalmente (e moi a miúdo situadas xerarquicamente nunha escala de maior a menor valor), aínda que non sempre coincidiron no número e na definición das mesmas (Banton, 1979; Hannaford, 1996).

Para Edwards, as razas gala e címbrica, que pertencían á familia céltica e que constituían a maioría da poboación francesa, presentaban non só unhas características físicas ben marcadas, senón tamén un carácter de seu, un «xenio», unha personalidade propia que se reflectía nas súas maneiras de actuar e de pensar, en todas as manifestacións das súas actividades (lingua, costumes, tradicións, institucións...). Pero máis importante era que Edwards insistía na permanencia de todos estes trazos particulares a través dos séculos (especialmente os físicos, o ámbito no que el máis se centraba). El cría na transmisión cáseque íntegra desa herdanza racial ó longo das xeracións: na súa opinión os franceses actuais presentaban os mesmos trazos físicos cós galos que se enfrontaran ás lexións romanas, e disto podía concluir Edwards unha continuidade esencial na poboación, dende a antiga Galia á Francia actual.

Niso o pensamento racial de Edwards diferenciábase en boa medida de moitos dos antropólogos que o precederan. Autores tan influíntes no

"CUADERNOS DE ESTUdIOS GALLEGOS", Tomo XLVII, Fascículo 113, Santiago 2000. 
artellamento da ciencia antropolóxica como Buffon ou Blumenbach, se ben definiran as razas humanas mediante criterios esencialmente biolóxicos e tamén concibiran estas como grupos con características físicas, mentais e culturais propias herdables a través do tempo, sen embargo poñían máis énfase na posibilidade de transformación das razas que na súa inmutabilidade. Isto debíase a que a adopción dunha posición monoxenista a respecto da humanidade (é dicir, a crenza en que todos os seres humanos formaba parte de unha única especie) obrigáballes a recoñecer que a partir dunha primeira humanidade homoxénea derivara toda a diversidade racial posterior. A explicación monoxenista máis aceptada (aínda que non a única) vía a causa desta subsecuente diversidade na acción continuada de «axentes exteriores» que modificaban os trazos humanos externos (non esenciais): influencias do clima e da alimentación, distintos modos de vida e de graos de civilización, cruzamentos, etc. Pero alén destas modificacións «superficiais», a humanidade seguía a ser unha na súa orixe e «natureza». Así, a esta escola monoxenista éralle forzoso recoñecer que as razas non eran inmutables, senón que podían estar sometidas a constantes alteracións por mor de distintas forzas «exteriores».

A tese de Edwards implicaba todo o contrario: el era partidario da inmutabilidade das razas, porque só así era quen de demostrar con total seguridade a pertenza do pobo francés á familia céltica. Nin as variacións climáticas, nin os cruzamentos con outros pobos, nin os cambios nos modos de vida, eran quen de modificar os caracteres particulares dunha raza, tanto físicos como psicolóxicos (e con estas afirmacións Edwards achegábase máis ás teorías polixenistas, que falaban dunha humanidade dividida en distintas especies/razas orixinarias, cada unha delas cunhas características inmutables). Desta maneira este médico francés podía afirmar que os cranios dos seus compatriotas contemporáneos eran idénticos ós dos galos e dos cimbrios que se atopaban nas antigas sepulturas; ou que a maneira de ser dos seus paisanos era practicamente a mesma cá dos seus devanceiros celtas, como consecuencia da transmisión dese «xenio» da raza.

Así, por obra e gracia de Edwards (que á súa vez se apoiaba nunha longa tradición historiográfica e nos estudios de historia natural) o vello mito da historiografía francesa de «nos ancêtres les Gaulois» acadaba a súa confirmación científica a través das teorías raciais da época. O elemento racial convertírase nun factor fundamental á hora de definir a identidade francesa.

"CUADERNOS DE ESTUdIOS GALLEGOS", Tomo XLVII, Fascículo 113, Santiago 2000. 
A influencia dos presupostos e dos métodos antropolóxicos de Edwards non se fixo agardar, e a teoría da fixeza dos tipos raciais convirtiuse nunha especie de dogma durante as décadas seguintes, incluso entre moitos autores de tendencia monoxenista (Blanckaert, 1988).

Esta última afirmación sobre a súa posterior influencia pode explicar precisamente a que se debeu esta curta introducción sobre a obra de Edwards e o pensamento racial da primeira metade do século XIX; porque creo que non é posible comprender totalmente as opinións de Murguía verbo da raza sen facer referencia a estes antecedentes, pois a pegada das ideas de Edwards é claramente visible no autor galego.

\section{O pensamento racial de Murguía: A influencia de W. F. Edwards}

"En efecto, la fisiología, como la lingüistica, ha venido á descubrir los lazos indestructibles que unen á los hombres de hoy con los hombres de quienes descienden, y con aquellos que, ramas de un mismo tronco, se parecen como hermanos, aunque se hallen separados por el tiempo y la distancia» (Murguía, 1901:243).

Esta frase do polígrafo corunés -a fío da súa aprobación dun comentario de Edwards verbo da importancia da fisioloxía (que neste contexto cómpre entender como sinónimo de antropoloxía física e do estudio das razas humanas)- condensaba o fundamental da influencia do antropólogo francés sobre o noso autor, que en varias ocasións ó longo dos seus escritos citará Des caractères physiologiques des races humaines como apoio ás súas teses celtistas. Porque ó igual que fixera Edwards no caso francés, Murguía quixo establecer «cientificamente» (segundo os parámetros de entón) as bases étnicas do pobo galego. Igual que Edwards, Murguía tiña como obxectivo impor a súa teoría acerca da orixe racial dos galegos por riba doutras teorías alternativas: se aquel afirmara o elemento céltico fronte ó xermánico na historia de Francia, Murguía quería demostrar a orixe celta da poboación galega fronte a outras tradicións historiográficas que lle atribuían ós galegos unha orixe non-celta, quer grega, quer íbera.

E para iso Murguía tiña que facer ver que a súa teoría era a máis «científica»; que estaba avaliada polo prestixio dos máis recentes saberes e prácticas do momento. De aí que á hora de presentar probas da orixe celta dos galegos acudise á historia, á arqueoloxía, á lingüística, á etnografía e -o que máis nos interesa agora- ás teorías raciais da época.

"CUADERNOS DE ESTUDIOS GALLEGOS", Tomo XLVII, Fascículo 113, Santiago 2000. 
Ó seguir esta estratexia Murguía podía demostrar coñecer boa parte da producción erudita europea do momento, tanto as súas teorías como a súa metodoloxía; e ademais poñía de manifesto o seu interese na investigación e na necesidade de contar con bases seguras (documentos, restos arqueolóxicos, estudios lingüísticos e etnográficos...) á hora de artellar a historia da nación galega. Con todo, non habían faltar as ocasións nas que Murguía sacrificase as súas pretensións de obxectividade e de cienticidade en aras da súa finalidade principal: a creación dunha identidade e dunha historia galegas que lle servisen como xustificación da súa ideoloxía e das súas arelas políticas.

En canto ó pensamento racial de Murguía, se ben cómpre recoñecer -como afirma Ramón Máiz (1984)- a influencia que nel se albiscaba das ideas raciais dos historiadores románticos da primeira metade da centuria (Macaulay, Carlyle, os irmáns Thierry...) e dos teorizadores do arianismo (o Conde de Gobineau, pero tamén Pictet e Ernest Renan); penso porén que as influencias máis importantes e máis inmediatas a respecto do concepto de raza proviñan dos antropólogos franceses de comezos do século, e nomeadamente de William F. Edwards e Pierre H. Bérard (continuador das teses do anterior). A influencia destes dous autores facíase ben visible no primeiro tomo da Historia de Galicia, publicado en 1865, onde Murguía asentaba os alicerces da súa tese celtista.

Porque, e a semellanza de Edwards, Murguía vai crear unha verdadeira identidade racial para os galegos: a pertenza á raza celta era o que nunha grande medida determinaba as características propias do pobo galego. É certo que a tese das orixes celtas dos galegos xa viña sendo presentada dende comezos de século por outros autores (Verea y Aguiar, Padín, Faraldo, Montero y Aróstegui), e que fora continuada polos seus coetáneos (Alvarado, Barros Sibelo, Vicetto...). Pero todos estes autores celtistas empregaban unicamente probas tiradas da historia, da arqueoloxía, da lingua e dos costumes galegos; en todos eles o argumento racial era mínimo, inexistente ou pouco claro. Será Murguía o primeiro para quen a raza (sen esquecer as outras probas) se convirta no argumento básico e principal das súas opinións sobre o pasado e a identidade de Galicia, e incluso da súa teorización da nacionalidade galega (Máiz, 1984). E será el o primeiro en presentar unha caracterización racial -física e psicolóxica- do pobo galego, e en artellar unha explicación biolóxica que dese conta da permanencia da raza celta como compoñente esencial das xentes que poboaban Galicia. 
Ademais ó inserir o seu celtismo noutras correntes máis amplas de pensamento de moita importancia neses anos, como eran as teorías raciais ou o arianismo, as súas teses gañaban (dende a perspectiva da época) en coherencia, forza e convicción, ó vérense «confirmadas» e complementadas polas teorías científicas que triunfaban por entón.

Para Murguía, ser galego significaba esencialmente pertencer á raza celto-ariana. A historia de Galicia como un pobo diferenciado comezaba coa chegada ó seu territorio das tribos celtas (os pobos pre-celtas non importaban, e a súa memoria podía perderse), e dende aquela ata a actualidade os galegos sempre presentaran as mesmas características, que eran comúns a todos os pobos celtas. $\mathrm{O}$ aspecto físico do galego actual coincidía coa descrición que os autores clásicos fixeran dos antigos celtas, e coas características que os antropólogos modernos (como Bérard ou o propio Edwards) consideraban propias dos pobos celtas (xa fosen galos ou cimbrios). O carácter dos galegos, os seus costumes, as súas crenzas, a súa linguaxe (malia ás aportacións latinas ou xermánicas posteriores), ou algunhas das súas institucións (como o foro)... eran tipicamente célticos, e transmitíranse intactos ó longo dos séculos de xeración en xeración. É dicir, que Murguía, como Edwards, cría na inmutabilidade -física, psicolóxica, cultural-dos tipos raciais, na fixeza das razas; e como el, precisaba deste presuposto para demostrar a veracidade da súa versión verbo da orixe étnica do seu país. Nesta crenza apoiábase unha boa parte da visión que Murguía tiña sobre Galicia.

Para sermos máis precisos. Esa crenza na inmutabilidade racial estaba baseada nas teorías de Edwards, como el mesmo recoñecía:

"El sabio fundador de la sociedad ethnológica de París [é dicir, W. F. Edwards] ha probado con la lógica poderosa de los hechos y con la luz de la ciencia, que muchos de los diversos tipos de la gran familia humana se conservan puros y que no basta ni la influencia del clima para modificar los caracteres distintivos de cada tipo, ni los diversos cruzamientos para alterarlos de una manera decisiva. Esta gran verdad la hemos visto confirmada en nuestro mismo país de manera decisiva» (Murguía, 1865: 208).

Con estas afirmacións quedaba fóra de dúbida que Murguía seguía a Edwards á hora de aceptar a fixeza dos tipos raciais; e, como el, negaba 
que as influencias climáticas e os cruzamentos puidesen transformar as razas $^{2}$.

Aínda máis, Murguía tamén seguía ó antropólogo francés cando se trataba de atopar unha explicación para as causas desta inmutabilidade racial e á hora de buscar un modo de clasificar a raza ou razas que tiñan presencia no país.

Edwards aseguraba que, malia a darse frecuentes cruzamentos entre as distintas razas, os tipos raciais mantíñanse intactos. Para explicar esta aparente contradicción argumentaba que a unión entre membros de razas diferentes, pero próximas entre elas (como por exemplo entre as múltiples razas brancas ou europeas), non producía unha descendencia que presentase características mesturadas dos dous tipos, senón que as características dunha desas razas (normalmente a máis forte ou a máis abundante) pasaban a ser herdadas integramente pola descendencia. Desta maneira, e a pesar dos cruzamentos, os tipos predominantes mantínanse puros, sen mestura.

A esta explicación engadía Edwards os efectos inhibidores do isolamento entre as razas, quer por motivos xeográficos (separación física), quer por motivos socio-políticos (existencia de castas endóxenas, segregación social, etc.) (Blanckaert, 1988).

E esas eran tamén as explicacións que adiantaba Murguía para dar conta da persistencia da raza celta en Galicia. Pesie a recoñecer a presencia no país ó longo da historia doutras razas en contacto coa celta (fenicios, gregos, cartaxineses, romanos), concluía que estas nunca foran un factor importante no compoñente étnico da poboación galega, que seguía

\footnotetext{
${ }^{2}$ Xa en 1889, no seu libro El Regionalismo Gallego, Murguía seguía a afirmar a fixeza das razas: «Después de todo, nosotros no somos los únicos que, sabiendo que se conservan en las razas tanto los rasgos morales como los fisicos, creemos reconocer los primitivos en los que son propios de los descendientes de una de ellas» (Murguía, 1889: 44-45). E recoñecía que «la mayoría de los antropólogos reconocen la ley de la permanencia de los tipos» (ibid: 44); aínda que esta vez non citaba a Edwards (que morrera en 1842), senón que se mostraba máis en consonancia coa ciencia do momento ó citar a Broca e a Topinard.

Sen embargo a segunda edición do tomo primeiro da Historia de Galicia (1901) mantiña intactos os argumentos tirados de Edwards. De feito, tanto polos obxectivos, como polas teorías e a metodoloxía, as opinións raciais de Murguía estiveron sempre máis perto das de Edwards ca das de Broca.
}

"CUADERNOS DE ESTUDIOS GALLEGOS", Tomo XLVII, Fascículo 113, Santiago 2000. 
a ser de xínea celto-ariana. $\mathrm{O}$ escaso número de persoas desas outras razas que habitaran o territorio galego, a súa localización en puntos moi concretos do país, así como o seu isolamento a respecto do resto da poboación, explicaban en parte esa mínima influencia (e tamén o feito de que aínda se puidesen atopar na actualidade algúns grupos illados dos seus descendentes a xeito de testemuños das vagas migratorias posteriores ós celtas).

Pero era sobre todo a «lei dos cruzamentos» enunciada por Edwards (aínda que neste caso a citase nas palabras de Bérard) a que Murguía adiantaba como causa principal, causa que aínda hoxe garantía a pureza da raza:

"cuando el padre y la madre pertencen á dos tipos diferentes y marcados, el fruto de su union viene al mundo con los caracteres de una de las dos razas. Ni se confunden ni se borran, ni forman un nuevo tipo (...) Se sabe que el caracter moral de la raza celta se resiente de cierta pasividad y ternura, que indujo á algunos á denominarla raza femenina; pues bien, casi siempre que un habitante de los demas países españoles viene á vivir á Galicia y se une á una muger de raza celta, esta predomina y los hijos tienen todos los rasgos comunes al tipo á que ella pertenece, soliendo, muchas veces, ser aptos, en especial para las artes liberales, ó distinguirse por sus no comunes dotes de inteligencia» (Murguía, 1865: 213).

Igualmente, tanto Edwards como Murguía van empregar o mesmo método para o recoñecemento de tipos raciais: a análise visual, puramente subxectiva e impresionista (sen a axuda de ningún tipo de aparellos antropométricos), dos trazos faciais (cor da pel, ollos, nariz, cabelo...) e da forma do cranio... e a atribución arbitraria deses trazos a determinados tipos raciais. Na opinión do segundo era posible distinguir cunha simple ollada, observando os trazos físicos da poboación galega actual, os descendentes, xa non só dos celtas, senón tamén os dos fenicios, gregos, romanos ou dos piratas normandos. En Murguía esa «maxia do antropólogo»-que creaba clasificacións e xerarquías humanas axudándose dos aparellos de medición- convertíase en puro pasatempo intuitivo e estético practicado durante os seus desprazamentos polo país. Gracias á súa habelencia fisiognómica, el era quen de deseñar a grandes pinceladas o mapa racial da Galicia decimonónica. A diferencia doutros teóricos raciais que 
podían acudir á paleontoloxía para demostrar a fixeza das razas, comparando os cranios das poboación prehistóricas cos das actuais, Murguía, e a falla de que se realizasen en Galicia investigacións arqueolóxicas e antropolóxicas, víase incapaz de usar esa proba adicional, o que non deixaba de lamentar en máis de unha ocasión (Murguía, 1866: 34) ${ }^{3}$.

De todos modos, se non podía acudir á paleontoloxía ou a datos antropométricos actuais na procura de apoio, sempre tiña como recurso facer súas as afirmacións dos antropólogos franceses, que durante as décadas anteriores definiran as características faciais e craniais da raza celta, para logo aplicalas á poboación galega, tanto á actual como á pre-romana. $\mathrm{E}$ así, decidindo que o tipo céltico predominante en Galicia fora, e seguía a ser, o galo (aínda que, en menor medida, tamén se atopaba o cimbrio), describía as súas marcas de identidade seguindo a Bérard -"cabeza mas redonda que oval, facciones redondeadas y mediana estatura, la nariz no viene recta desde la frente como en la raza árabe, sino que la separa una depresion» (Murguía, 1865: 215-216); namentres que o tipo romano, que tamén se atopaba -aínda que en clara minoría- na poboación galega, era descrito seguindo a Edwards (ibid: 216).

Desta maneira Murguía non se limitaba unicamente a crear un pasado e unha descendencia (celta) para os galegos -algo que xa fixeran outros antes ca el. El ía máis lonxe ó crear, seguindo as tendencias dos saberes do momento (historia, arqueoloxía, lingüística, antropoloxía), unha verdadeira identidade racial para eles, o que non fixera ninguén antes. Gracias a el o pobo galego adquiría, a través da herdanza céltica, unhas características físicas determinadas, unha maneira de ser, un «xenio» de raza, e unhas potencialidades de seu... E todo isto era algo que o marcaba, e que o marcaría, durante toda a súa existencia.

Pero antes de pasar a ver con algo máis de detalle as implicacións desa identidade racial artellada por Murguía, cómpre deteñérmonos un intre

\footnotetext{
${ }^{3} \mathrm{O}$ médico Ramón Otero na súa Galicia Médica (1867) foi o primeiro en empregar datos paleontolóxicos para dilucidar a compoñente étnica dos galegos. Utilizando datos tirados dos cranios achados nos monumentos megalíticos do país e comparándoos cos cranios da poboación actual, falou da persistencia dunha «raza galaica», mestura de celtas e de íberos; raza que se mantivera estable a pesar doutros aportes étnicos a causa das mesturas con outros pobos (aportes que Otero tentaba albiscar a través dos trazos dos cranios).
}

"CUADERNOS DE ESTUDIOS GALLEGOS", Tomo XLVII, Fascículo 113, Santiago 2000. 
nas súas opinións sobre as razas en xeral para comprendermos mellor aquelas.

\section{O pensamento racial de Murguía: Ambigüidades e xerarquías}

Antes de nada débese recoñecer que Murguía nunca chegou a dar unha definición de raza. Por máis que estivese a empregar continuamente este termo - que ademais recibía unha boa cantidade de calificativos (raza branca, indo-europea, celta, xermana, galega, española, sueva, grega, romana, fenicia, latina, semita, árabe, bretona, lusitana...)- en ningún momento clarexaba o que para el significaba, nin cales eran os criterios empregados á hora de determinar esas divisións raciais. Só quedaba realmente claro a importancia que lle concedía, de xulgarmos polas constantes referencias.

Esa indefinición provocaba moitas veces a ambigüidade do propio termo. En efecto, en ocasións falaba da raza ariana ou indo-europea, dentro da que incluía a celtas, xermanos, latinos, gregos, etc. Outras veces falaba de raza celta, raza xermana ou raza latina... que estaban incluídas, como xa sinalara, na raza ariana. E aínda noutros momentos falaba de raza galega, raza irlandesa, raza bretona... xentes todas de raza celta; ou de raza sueva e de raza goda, dentro da raza xermana... E así noutros casos. E nunca conseguimos saber cales eran os criterios que seguía nesas divisións e subdivisións dunha mesma raza orixinal (ariana) - ¿físicos, lingüísticos, culturais?; nin como se debía entender que unha raza como a ariana estivese pola súa vez dividida e subdividida noutras múltiples razas diferentes (celta, xermana, latina, bretona, sueva, goda, etc.); nin que significaban realmente esas subdivisións. Noutras ocasións, pola contra, xa prefería falar de razas (en plural) semitas, xermanas, latinas ou celtas, indicando quizais o seu desexo de salientar a existencia de variedades dentro dun tipo racial «base» (porén, sen deixar claro de novo os criterios empregados ou a coherencia e sentido da propia subdivisión).

Idéntica ambigüidade atopabámola cando se trataba de dar unha explicación verbo da propia orixe das razas humanas: ¿eran estas variedades de unha única especie humana como querían os monoxenistas?¿ou as razas máis afastadas entre si -a branca, a negra, a amarela-correspondían a especies diferentes, segundo afirmaban os polixenistas?. Por máis que daquela esta cuestión fose de extrema importancia, e fose debatida continuamente, el non daba unha resposta nidia e definitiva.

"CUADERNOS DE ESTUDIOS GALLEGOS", Tomo XLVII, Fascículo 113, Santiago 2000. 
Ata certo punto ás veces semellaba querer favorecer unha explicación polixenista. A insistencia na inmutabilidade das razas, por máis que puidese ser aceptada polos monoxenistas (o filósofo Kant era un exemplo sobranceiro), era un argumento moi querido dos polixenistas e era o máis acaído ós presupostos desta escola antropolóxica. O propio Murguía facíase eco, no abrente do século XX, do vello argumento polixenista (presentado xa a principios do XIX polo médico norteamericano Samuel Morton) da diferenciación orixinal e da permanente inmutabilidade dos tipos raciais:

«la arqueología nos prueba que hace millares de años permanecen sin variación los tipos negro, egipcio y judio» (Murguía, 1901: 450-451).

Os polixenistas estaban interesados en demostrar a inmutabilidade das razas ó longo da historia para poderen concluír que dende o momento mesmo da súa aparición na Terra a humanidade estivera xa dividida en razas diferentes (e non que estas eran resultado da diversificación posterior duns primeiros humanos homoxéneos, como aseguraban os monoxenistas); razas que en realidade eran especies diferentes que xurdiran orixinariamente en diversas partes da terra adaptadas ás condicións propias de cada rexión.

Tendo en conta isto, e perante parágrafos como o seguinte, a verdade é que nos podemos preguntar seriamente se Murguía «abrazou» o polixenismo:

"Lo racional es pensar en que llegó un momento en que todas ellas [as razas] -las inferiores como las superiores-existieron á un tiempo en los diversos puntos del globo en donde las condiciones climatológicas lo permitían á cada una de por sí, [e] que los cruzamientos fueron sin importancia y siempre en detrimento de las razas inferiores» (Murguía, 1901: 448-449).

E podémonos plantexar idéntico interrogante ó sabermos do forte rexeitamento que Murguía amosaba cara ós cruzamentos entre razas distintas e «opostas» entre si (brancos e negros, brancos e indios ou arios e semitas, por exemplo), pois afirmaba que como consecuencia dos mesmos a descendencia resultante eran «seres inferiores moral e intelectualmente» (e poñía como exemplo negativo o caso de Norteamérica; Murguía, 1865: 
479). Malia a non ser un argumento e unha actitude exclusiva dos polixenistas, a oposición ós cruzamentos raciais si que xogaba un papel importante nas súas teorías (chegando incluso a negaren a posibilidade de cruzamentos fértiles entre as diferentes «especies» humanas; $c f$. Stocking, 1968).

Con todo, e a pesar destes indicios (pequenos pero suxerentes), non chegarei a concluir que Murguía foi un autor polixenista. De facelo, non tería en conta os varios matices do seu pensamento nin as súas implícitas afirmacións de monoxenismo; nin tampouco as transformacións que as teorías raciais viñan experimentando dende a primeira metade do século XIX. De feito na cita anterior, que aparentemente se achegaba tanto ás argumentacións polixenistas, a expresión «llegó un momento» denotaba en si que a división racial puidera non ser orixinaria e que só se dera posteriormente, converténdose en adiante nunha realidade inmodificable.

Máis definitivo á hora de asignarlle a Murguía unha postura monoxenista era o feito de que el falase en ocasións da «raza humana» (e aquí o termo «raza» debe ser entendido no sentido de «especie») ou da "gran familia humana», dando a entender que concibía unha única especie humana, pesie ás grandes distancias que puidese haber entre as distintas razas da mesma; ademais, Murguía non foi home dado a manter posicións radicalmente «heterodoxas», contrarias á opinión oficial ou maioritaria da Igrexa, a respecto da cuestión antropolóxica máis debatida do momento: a orixe da humanidade (el rexeitaba o transformismo e a existencia do Home Terciario)... e o polixenismo sempre foi (a carón da teoría da orixe simia do ser humano) unha das grandes «bestas negras» da doutrina católica (Pereira González, 1996). Polo demais, o historiador George W. Stocking ten demostrado como na segunda metade do século XIX se produciu unha sorte de asimilación de argumentos polixenistas -como o da fixeza das razas e o da dificultade dos cruzamentos entre razas moi diferentes- por parte de autores monoxenistas, sen que estes renunciasen a considerar a todos os seres humanos membros de unha soa especie (Stocking, 1968).

Por todo isto opino que é mellor considerarmos a Murguía como un monoxenista que adoptou (por necesidades teóricas e/ou por conviccións persoais) certas teses polixenistas (que daquela moitos autores integraran en contextos monoxenistas), pero sen por iso atacar frontalmente o dogma católico da unidade da especie.

"CUADERNOS DE ESTUDIOS GALLEGOS", Tomo XLVII, Fascículo 113, Santiago 2000. 
Murguía non explicaba o que el entendía por raza, nin se paraba a discutir cal podía ser a orixe da diversidade racial. Pero quedaba bastante claro que para el unha raza era un grupo humano que se caracterizaba por unha serie de trazos físicos e de trazos psicolóxicos e intelectuais. Cada raza posuía un aspecto físico de seu, as súas capacidades intelectuais e morais, o seu carácter e as súas potencialidades para o progreso. E todo isto quedaba reflectido no seu xeito de vida, no grao de civilización que chegase a acadar, na súa lingua ${ }^{4}$, nos seus costumes, crenzas e institucións. De feito eran esas características raciais as que determinaban e condicionaban todos estes elementos da vida dun pobo. Neste sentido pódese falar da existencia dun determinismo racial no pensamento de Murguía: a raza era o factor esencial e determinante na existencia e no destino dun pobo. Era a composición racial o que condeaba a un pobo a unha inferioridade permanente; ou o que facía del a raza elexida para dominar o mundo.

Pero non é tan doado saber cal era a xustificación que ofrecía Murguía para dar conta do seu determinismo, pois en ningún lugar explicaba nin deixaba albiscar cales eran as bases do mesmo. Se outros autores abrazaban un determinismo racial de base inequivocamente biolóxica -de presupostos materialistas-, facendo derivar as capacidades de cada raza da súa organización física (principalmente do tamaño, da forma e da organización cerebral); Murguía simplemente establecía unha correlación entre as distintas características e manifestacións de cada raza (por exemplo, falaba dunha raza ariana, branca, superior, intelixente e progresiva) pero sen establecer entre elas posibles relacións de causa/efecto, e sen dar conta do por que da superioridade ou da inferioridade dunha raza determinada (non explicaba, por exemplo, que a superioridade dos pobos arios europeos se debese a que tiñan un cerebro máis grande $\mathrm{e}$ máis complexo có das razas non brancas). Sinxelamente, el daba por sentada a existencia de razas superiores e de razas inferiores, pero sen preocuparse en explicar as causas das súas posicións na xerarquía racial que el sustentaba.

\footnotetext{
${ }^{4}$ Así como existían razas superiores e inferiores, había, para Murguía, linguas superiores e inferiores, que se correspondían cos distintos chanzos da xerarquía racial: «¿es factible - preguntábase ó comezo da súa Historia de Galicia-que un pueblo de raza superior pueda adoptar facilmente la lengua de los que le son inferiores?» (Murguía, 1865: 9). El negábao, en consonancia coa súa repugnancia cara ós «híbridos» raciais.
}

"CUADERNOS DE ESTUDIOS GALLEGOS", Tomo XLVII, Fascículo 113, Santiago 2000. 
Porque, e aínda que sen desenvolver con detalle, no seu pensamento aparecía moi claramente unha xerarquía racial que tendía a situar no cumio da mesma (non é nada estraño) aquela raza da que o propio autor (e con el todo o pobo galego) se consideraba integrante: a raza ariana ou indo-europea (a raza branca ou xafética).

Para el, a ariana era a raza superior por excelencia: intelixente, activa, traballadora, moderna... Dotada (aínda que non explicase o por que) dunha capacidade inesgotable para progresar. En verdade que ás veces parecía como se para Murguía o pobo elexido por Deus fose a raza ariana, e non os hebreos como afirmaba a tradición xudeo-cristiá:

"[as razas arianas] como si en ellas hubiese algo de divino, marchan siempre, marchan confiadas en la diaria victoria, que jamás les negó el cielo» (Murguía, 1888a: 15-16).

Con todas estas opinións Murguía non facía senón seguir ós máis sobranceiros teorizadores do mito ario, que daquela se atopaba nos comezos do seu apoxeo (Poliakov, 1971; Olender, 1989): Gobineau, Renan, Pictet... as obras dos cales citaba a miúdo. Porén, e a pesar de compartir moitas das súas asuncións, Murguía establecía as distancias a respecto do arianismo do Conde de Gobineau. Se compartía con el a admiración polos arios e a consideración deles como a raza superior e civilizadora por excelencia, non admitía o «pesimismo racial» do conde francés; pesimismo que levaba a Gobineau a agoirar a total desaparición da raza aria -e polo tanto da civilización- como consecuencia da «contaminación racial» producida polos cruzamentos con outras razas inferiores (negras, amarelas).

Murguía, que como xa se viu predicaba a inmutabilidade racial e a oposición ás mesturas raciais, rexeitaba as conclusións do conde por negativas e agoreiras, namentres reafirmaba a súa confianza nun futuro brillante das razas arianas (e, por extensión, do pobo galego).

Esta era a súa resposta ó determinismo pesimista de Gobineau, na que amosaba asemade a súa concepción providencialista da superioridade aria e o seu horror perante ós cruzamentos entre razas superiores e inferiores:

"Si Dios ha prometido, con gran razón por cierto, á los hijos de Japhet [é dicir, á raza ariana] el dominio de la tierra, es necesario que se

"CUADERNOS DE ESTUdIOS GALlEGOS", Tomo XLVII, Fascículo 113, Santiago 2000. 
cumpla su promesa, que la raza blanca viva y domine con vida enérgica, y que no llegue al término de su viaje, despues de mezclar sus límpidas ondas, con las de todas las corrientes impuras, para caer, por último, aguas completamente muertas y corrompidas, en los ilimitados abismos de la nada» (Murguía, 1865: 481).

Conceptos-símbolo como o da «impureza», a «corrupción» e a «nada abismal» referidos ós cruzamentos entre razas amosaban ben ás claras o seu elitismo racial e a súa profunda aversión á mestura de sangue superior con aquel que lle fose inferior, pero sen chegar a tirar deste sentimento unha visión negativa da historia como a de Gobineau.

Nun nivel inferior da xerarquía racial situaba Murguía a raza semita ${ }^{5}$. Como foi frecuente no pensamento occidental dende o século pasado, a louvanza da raza ariana ía acompañada de ataques contra os pobos semitas -especialmente os xudeos- e da minusvaloración da súa historia e da súa cultura, establecéndose así unha dicotomía ario/semita que as máis das veces tendía a se convertir nunha oposición superiores/inferiores (Poliakov, 1971; Olender, 1989).

O discurso anti-semita de Murguía seguía a grandes trazos as liñas marcadas polos principais representantes do arianismo; en concreto, albiscábase nidiamente a influencia de Ernest Renan (Murguía citaba en ocasións os seus Histoire général et système comparé des langues sémitiques e De la part des peuples sémitiques dans l'histoire de la civilisation) cando o autor galego establecía unha dicotomía entre a raza aria activa, intelixente e progresiva, e os pobos semitas (falando en concreto dos árabes) coa súa civilización inmóbil, decadente, superficial e estéril (Murguía, 1891a: 25-30; 1891b).

\footnotetext{
${ }^{5}$ No século XIX, xudeos, árabes ou os antigos fenicios, considerábanse representantes da raza semita. A carraxe e as aldraxes anti-semitas dirixíanse, sobre todo, contra os hebreos. Sen embargo en Murguía, paradoxalmente, aparecía unha imaxe positiva dos xudeos, pobo ó que consideraba activo, intelixente e traballador, á vez que lamentaba a súa expulsión do reino por parte dos Reis Católicos (Murguía vía nesta expulsión a ruína de Galicia e de todo o reino de Castilla) (Murguía, 1888a: 465-474).

O discurso anti-semita de Murguía dirixíase contra os fenicios e, principalmente, contra os árabes; nos dous casos sempre pretendía negar a influencia destes pobos sobre o compoñente étnico e a cultura de Galicia. Este discurso tiña , ademais, unha funcionalidade claramente política (Máiz, 1984).
}

"CUADERNOS DE ESTUDIOS GALLEGOS", Tomo XLVII, Fascículo 113, Santiago 2000. 
Se os arios se caracterizaban pola súa «enerxía vital», que lles permitía erguer complexas civilizacións e perfeccionarse continuamente, os semitas eran deixados a parte da marcha progresiva da historia (que só correspondía ós arios) e minusvalorizados coa aldraxe de seren unhas «razas impotentes» (Murguía, 1891a: 27); o que non lle impedira a Murguía anos antes, no seu libro Galicia (1888), falar dos xudeos como dun pobo activo e traballador, responsable da prosperidade dos países nos que se asentaban.

Ademais a visión que Murguía tiña sobre os semitas (fenicios e árabes) correspondíase en boa medida coa imaxe que do «outro» oriental se viña mantendo en Occidente dende a Antigüidade clásica. $\mathrm{O}$ «oriental» (categoría que abranxía indistintamente unha ampla diversidade de pobos e de culturas -heteroxeneidade que só se entendía dentro da súa representación como contrario a Occidente-Europa) era sensual e lascivo, afeminado, feble e covarde, argallante e traidor, vivindo baixo reximes despóticos, cruel e fanático, atrasado... (Hall, 1989; Said, 1990). En calquera caso, eses calificativos só tiñan sentido dentro desa oposición máis xeral occidente/oriente-europeo/asiático-ario/semita, na que o «outro», o oriental ou o semita, era a cara oposta e negativa do «nós». Deste xeito, a definición do «outro» non era unicamente un xeito de coñecelo e de clasificalo, e de minusvaloralo, senón tamén un medio de auto-identificación a través dun xogo de contrarios (sendo sempre as características negativas dos «outros» o oposto ás virtudes de «nós» europeos).

Nun chanzo aínda máis baixo da súa xerarquía situaba as razas de cor, os pobos indíxenas de África, América, Asia e Oceanía. Porque os semitas, a pesar de seren inferiores ós arios, tiñan unha «civilización», aínda que fose decadente e estéril. Pero ós africanos, ós indios ou ós «aborixes» australianos, negáballe incluso un posto na historia humana. Por mor do seu primitivo estado ficaban fóra da marcha progresiva da humanidade, fóra da civilización, estancados como estaban nunha eterna prehistoria, vexetando nas súas selvas e bosques milenarios. Esa era a imaxe predominante na Europa decimonónica, e a que tamén mantiña Murguía: as razas non brancas, razas inferiores, ó longo da historia "permanecieron en el grado de inferioridad que les es propia y en que se encuentran todavía» (Murguía, 1901: 449).

En realidade Murguía falando destas razas primitivas chegará tan lonxe como para negar a unidade psíquica da humanidade, é dicir, o recoñece-

"CUADERNOS DE ESTUdIOS GALLEGOS", Tomo XLVII, Fascículo 113, Santiago 2000. 
mento de que todos os seres humanos posuían as mesmas potencialidades intelectuais e realizaban os mesmos procesos mentais.

É verdade que non a negaba de maneira frontal e polémica, senón que o facía de esguello, a través dunha crítica ós presupostos e á metodoloxía do evolucionismo socio-cultural. Os evolucionistas (como Tylor ou Lubbock) fixeran súa a tese da Ilustración sobre a unidade psíquica da humanidade, pois só con ela podían explicar como era posible unha evolución universal a través dos mesmos estados de civilización: o feito de compartiren todos os humanos as mesmas capacidades e os mesmos procesos mentais implicaba que, baixo os mesmos influxos e limitacións, as respostas dadas a estes serían idénticas, o que explicaba o proceso de evolución socio-cultural uniforme. Todos os humanos pasaran orixinariamente-ou debían pasar máis tarde ou máis cedo-polos mesmos estados de civilización, nun proceso continuo e ascedente. Os europeos, os primeiros en acadaren o cumio dese proceso civilizador, con toda a súa sofisticada civilización actual viviran nun principio como as tribos máis salvaxes e atrasadas de África ou Australia. Coñecer a vida, os costumes e as crenzas destas últimas era pois facer unha viaxe no tempo para enxergar a mesma existencia dos primitivos europeos, incluso daqueles arios dos que se sentía tan orgulloso Murguía. A pesar do forte etnocentrismo que esta teoría implicaba, nela subxacía porén a crenza na igualdade potencial de toda a humanidade (crenza que sen embargo sería atacada dende varias frontes durante todo o século XIX; $c f$. Stocking, 1968)

Pero precisamente estes eran os presupostos evolucionistas (así como o método comparativo e a procura dos survivals, ou supervivencias de crenzas primitivas, no folklore europeo) que o escritor coruñés rexeitaba, co argumento claramente racista de que "no se podrá decir nunca que el estado primero en las razas inferiores es igual al de las superiores. Viven las primeras en un estado primitivo permanente, mientras las últimas, apenas le conocen, cuando ya se han desprendido de sus cadenas. Hay más: el ario en sus comienzos es superior al negro en todo el esplendor de su civilización posible» (Murguía, 1888b: 140-141).

Un autor evolucionista contemporáneo de Murguía como Edward B. Tylor -que seguía moi de perto a herdanza da Ilustración no relativo á unidade psíquica da humanidade (Stocking, 1968)- concibía a evolución socio-cultural como o progresivo perfeccionamento das capacidades intelectuais que eran xerais a todos os humanos. Gracias a ese desenvolve-

"CUADERNOS DE ESTUDIOS GALLEGOS", Tomo XLVII, Fascículo 113, Santiago 2000. 
mento as persoas eran quen de coñecer mellor e de representar con máis exactitude o mundo que lles rodeaba, o que se traducía nun crecente control do seu medio físico e social (Stocking, 1987). É ben certo que Tylor e outros evolucionistas sostiñan que uns pobos realizaran ese proceso máis rápido e con maior perfección cós outros (por exemplo, un inglés antes ca un hotentote); pero non é menos certo que tamén estaban convencidos de que acadar a posesión plena das facultades intelectuais e racionais estaba ó alcance de toda a humanidade, precisamente debido á esa unidade psíquica orixinal. Que o fixesen era só cuestión de tempo e de circunstancias favorables.

Estes presupostos evolucionistas non facían máis que seguir de perto as ideas da Ilustración sobre a humanidade (e, en último termo, a da doutrina cristiá acerca da salvación de toda a humanidade mediante a aceptación da mensaxe de Cristo). Pero a crecente influencia do determinismo racista establecía unha barreira insalvable entre razas, ó concibir a cada unha delas como posuidora dunhas capacidades e potencialidades concretas que nunca sería quen de superar. E así, fronte á da unidade psíquica de toda a humanidade elevábase a idea de distintas humanidades (razas diferentes) con cadansúa configuración mental e psicolóxica, configuración que se imaxinaba herditaria e inmutable (este non era senón outro aspecto máis daquela influencia do pensamento polixenista sobre o pensamento racial da que falei máis arriba).

Neste contexto de reacción contra os postulados da Ilustración é no que hai que entender as afirmacións de Murguía sobre a inferioridade innata dos negros e doutras razas primitivas, así como a súa negativa a establecer calquera tipo de comparacións entre os arios e os negros (negativa que, dende logo, na súa opinión contribuía a reafirmar a "privilexiada» posición dos arios): era inútil tentar coñecer as primitivas crenzas dos arios acudindo ós pobos primitivos, ou explicar ofolklore europeo en termos de supervivencias de ideas propias das razas inferiores (animismo, totemismo), porque uns e outros nunca foron iguais; nin en cuestión de crenzas, nin de mentalidade, nin de capacidade intelectual... Non se podía comparar o superior co que lle era (e sería sempre) inferior:

«nadie dirá que las razas superiores, ni aún en su estado mental más rudimentario, concibieron y expresaron la idea de la divinidad á la manera que las inferiores. Cada una de ellas apareció con sus condi-

"CUADERNOS DE ESTUDIOS GALLEGOS", Tomo XLVII, Fascículo 113, Santiago 2000. 
ciones especiales y peculiares aptitudes, cada una las desenvolvió obedeciendo á sus tendencias y fuerza» (Murguía, 1888b: 140-141. O subliñado é meu).

$\mathrm{Na}$ última frase ficaba moi ben expresada esa crítica á unión psíquica de toda a humanidade: Murguía aseguraba que cada raza tiña diferentes condicións e aptitudes, ou, o que viña de ser o mesmo (coñecendo o contexto e as outras opinións do noso autor), que cada raza tiña distintas capacidades e potencialidades que limitaban ou favorecían -segundo os casos- o seu desenvolvemento. Sempre foron diferentes e así se manterían. Non era imaxinable que as razas inferiores fosen capaces algún día de elevarse ata o nivel intelectual e cultural das superiores. Nin que estas, algunha vez, tivesen sido como aquelas.

Vista esta radical diferenciación cabe preguntarse cal era o destino que Murguía enxergaba para esas razas inferiores. Desprovistas da capacidade de mellora e de progreso -capacidade monopolizada polos arios- ¿cal era o futuro que lles agardaba, choídas e atrapadas na súa existencia primitiva e inmóbil, e enfrontadas ó imparable avance civilizador da raza branca?. Murguía non o dicía claramente; tampouco debía ser un tema que lle preocupase en exceso. Pero podémonos facer unha lixeira idea a partir dalgúns breves comentarios que se atopan esparexidos, aquí e acolá, na súa extensa obra.

Realmente non era un futuro moi esperanzador. Falando do destino da poboación que vivía en Galicia e en toda Europa antes da chegada dos celtas - poboación que pertencía a unha raza inferior, finesa ${ }^{6}-$, comentaba de pasada o destino que lle agardaba a todas as razas inferiores en contacto con outras que lle eran superiores:

"es evidente, y lo demuestra la historia, que los pueblos de raza inferior, no pudiendo sufrir la presencia de los que le son superiores, se retiran, les dejan el campo libre ó desaparecen, no porque se les ester-

\footnotetext{
${ }^{6}$ Neste punto Murguía seguía, en parte, as teses do antropólogo sueco Anders Retzius -de grande predicamento na Europa de entón-que falaban dunha poboación pre-celta de raza finesa, braquicéfala e de cultura moi primitiva, que se vira substituída (exterminada ou expulsada cara á zonas periféricas -como Euskal Herria) por vagas de invasores arios, dolicocéfalos e de cultura máis avanzada (Blanckaert, 1989).
}

"CUADERNOS DE ESTUDIOS GALLEGOS", Tomo XLVII, Fascículo 113, Santiago 2000. 
mine á sangre y fuego, sino porque no puede su inteligencia con el órden de ideas que se estiende á su alrededor, y así segados por esta espada, para ellos sin piedad, que se llama civilización, perecen como victimas ofrecidas en holocausto de una ciega divinidad» (Murguía, 1865: 7).

Murguía non chamaba ó seu exterminio, nin á súa escravización (de feito en numerosas ocasións amosábase totalmente oposto á escravitude). Simplemente consideraba «normal» que as razas inferiores fosen sometidas polas superiores, que estas fosen as que dominasen sempre ${ }^{7}$. Igualmente, se a desaparición das razas non brancas era un feito que podía ser lamentado, era asemade inevitable, pois estas, como razas primitivas, non podían aturar a presión que para elas significaba a civilización. Opinións semellantes eran compartidas amplamente polos seus contemporáneos.

Con todo, Murguía non vía a historia como se for un escenario darwiniano no que se representase unha eterna loita a morte entre razas. Nin sequera facía da historia de Galicia unha imitación da «loita das dúas razas» presente na historiografía francesa. A pesar das loitas iniciais entre galaicos e romanos, esas dúas razas acabaran irmanándose (porén sen mesturarse racialmente) e compartindo os mesmos intereses e penalidades (Murguía, 1865: 22). Igualmente, e malia a algunhas referencias ó antagonismo entre arios e semitas (que correspondía á oposición galegos/ casteláns), tampouco chegaba ó punto de concibir a historia como un enfrontamento constante entre esas dúas razas opostas. As explicacións dos conflictos do pobo galego con outros pobos viñan dadas basicamente en clave económica, social e política, e non en clave de antagonismo racial. Algunhas referencias ó "combate encarnizado entre la raza semítica y la jafética (...), entre la Cruz y el Koran» (Murguía, 1865: 69) viñan reforzar a dicotomía Galicia/Castilla, pero non se elevaban á categoría de explicación histórica principal.

\footnotetext{
${ }^{7}$ A este respecto é moi significativa a seguinte frase acerca do destino das razas inferiores pre-celtas: «ó desaparecieron ante los invasores [celtas], ó reconociéndose sus tributarios, arrastraron (...) la vida á que por su condición de inferiores y de vencidos, quedaron desde luego sujetos» (Murguía, 1888b: 1.149. O subliñado é meu). Ese «desde luego» dinos que el aceptaba esa suxección como algo «natural».
}

"CUADERNOS DE ESTUDIOS GALLEGOS", Tomo XLVII, Fascículo 113, Santiago 2000. 
E a pesar desas mencións á inevitable desaparición das razas inferiores, tampouco consideraba explicitamente a loita racial -que debía ter como resultado inevitable o triunfo das superiores- como o motor do progreso, nunha aplicación á historia dos argumentos do denominado (erroneamente) «darwinismo social».

Concluíndo este apartado, pódese dicir que o pensamento racial de Murguía amosaba unha grande falta de sistematización. E isto non só porque o autor non era (nin se consideraba a si mesmo) un teórico racial, nin un «antropólogo» (no sentido que por entón se lle daba ó termo -estudioso, entre outras cousas, das razas humanas). Esa asistematización non facía senón reflectir cal era o seu verdadeiro interese e a súa finalidade: non eran, evidentemente, facer unha clasificación máis ou menos detallada das razas humanas ou das razas europeas (como fixeran antes Blumenbach, Desmoulins, Retzius ou Broca), nin artellar unha filosofía da historia en termos raciais (como fixera o conde de Gobineau). Eran ofrecer ó pobo galego unha historia e unha identidade de seu, das que ademais se puidese gabar. E para iso non precisaba de sesudas clasificacións ou teorías raciais. Abondáballe con demostrar a inmutable identidade celta do seu país -empregando para iso algunhas das ideas raciais do momento- e con facer seus algúns dos presupostos do arianismo. Se de cando en vez deixaba entrever opinións sobre as razas non arianas era para mellor afirmar a superioridade dos arios e o seu destino providencial (todo o cal redundaba en beneficio dos galegos, pobo que era dobremente ario pola súa liñaxe celta e polos aportes suevo/xermánicos). O seu interese na teorías raciais era puramente utilitario. Porén, se temos en conta as fontes por el utilizadas na consecución dos seus obxectivos, Murguía demostraba o seu coñecemento das correntes do momento -manexando sempre as que máis lle interesasen.

Por último, e despois de coñecermos a súa xerarquización racial, faise dificil estar de acordo coa opinión de Ramón Máiz, cando este autor afirma que por mor da ideoloxía liberal de Murguía as súas ideas raciais quedaban libres das implicacións máis «radicais». En concreto Máiz nega que a postura de Murguía, aínda que recoñecéndoa como nidiamente etnocéntrica, poida ser calificada de racista (Máiz, 1984).

A miña opinión é, sen embargo, outra. O etnocentrismo de Murguía está ben claro (os arios -europeos- son os creadores da civilización máis avanzada e valorada). Pero ese etnocentrismo estaba artellado sobre o

"CUADERNOS DE ESTUDIOS GALLEGOS", Tomo XLVII, Fascículo 113, Santiago 2000. 
factor racial; é dicir, que unha civilización superior era sempre síntoma -e resultado- dunha raza superior, e que unha raza inferior sería sempre incapaz de crear unha civilización elevada ou sequera de adaptarse a ela. Murguía establecía diferencias raciais insalvables entre a humanidade. Para el existían razas permanentemente inferiores (se ben non explicaba as causas). E esa inferioridade racial era o que daba conta do seu atraso cultural e xustificaba que fosen dominadas por outros grupos superiores. E tendo isto en conta, e seguindo as definicións máis correntes de racismo, as ideas de Murguía eran indubidablemente racistas.

\section{Unha identidade racial para os galegos}

Xa se viu máis arriba que o feito racial implicaba para Murguía unhas determinadas características físicas, psicolóxicas, intelectuais e culturais, así como unhas potencialidades para desenvolver a civilización e progresar.

O primeiro aspecto xa o tratei antes: Murguía vía o tipo físico racial celta -definido seguindo ós antropólogos franceses- perpetuado na meirande parte da poboación galega (aínda que recoñecía tamén a supervivencia dos aportes doutras razas -fenicia, grega, romana...-, pero sen mesturar coa maioría celta da poboación).

No que sigue tratarei os outros aspectos que implicaba esa identidade racial celta.

En primeiro lugar, a pertenza á raza celta implicaba unha maneira de ser especial, un «xenio» racial único, intransferible e inmutable. Era unha maneira de ser que se «levaba no sangue» (aínda que Murguía nunca explicaba como se transmitía o carácter racial), presente durante toda e existencia do pobo galego, dende os antigos galaicos que loitaron contra os romanos ata os seus compatriotas contemporáneos.

Murguía tampouco se paraba en detalladas explicacións psicolóxicas verbo do carácter celta (a súa orixe, as súas manifestacións, etc.). En troques, presentaba un listado de cualificativos que se supoñía definiran dende sempre o xeito de pensar e de actuar dos habitantes do país. Unha vez máis pasaba por riba de explicacións (para el) superfluas e ía directamente ó que lle interesaba.

Nesta singularización do «xenio» celta confluían tres correntes diferentes que en Murguía se unían e se complementaban (non sen certas tensións latentes).

"CUADERNOS DE ESTUdIOS GALLEGOS", Tomo XLVII, Fascículo 113, Santiago 2000. 
O galego, como celta, era valente, afouto, intelixente, amante da súa independencia (por iso loitara contra todos aqueles que tentaran limitala-cartaxineses, romanos, godos, árabes, nobreza ou o centralismo español), amante da súa terra e das tradicións herdadas dos seus devanceiros (que conservaba por instinto de raza); era tamén eminentemente relixioso e respectuoso cos seus mortos (como xa demostraran os antigos galaicos coas súas moitas divindades e co coidado ós mortos que reflectían os miles de monumentos megalíticos inzados por todo o país, sentimento que se conservaba nos costumes e crenzas actuais). A grandes trazos esta era a imaxe que a historiografía galega do XIX viñera transmitindo acerca dos celtas galaicos, dende Verea y Aguiar.

A segunda corrente que confluía en Murguía vía nos celtas unha «raza feminina», denominación cuñada por Ernest Renan e adoptada por outros escritores influíntes como Mathew Arnold. Así, para Murguía, o celta (o galego) era ademais dóce, triste e melancólico, dado ó sentimento, espiritual, de grande imaxinación e dotado para a arte e a poesía ${ }^{8}$-o que daba conta tanto do especial sentimento que o unía coa terra como das características únicas da literatura galega.

Por último seguía as teses arianistas, que realizaban unha descrición positiva do ario (neste caso do celta) a través dunha radical dicotomía coas razas semitas. A oposición que Murguía establecía entre celtas/suevos/arios e fenicios/árabes/semitas -que na realidade agachaba unha oposición entre galegos e casteláns/andaluces (que decote Murguía alcumaba como «pueblos semitizados»)- viña reforzar a súa caracterización dos celtas/galegos, atribuíndolles todas as virtudes das razas arias. Por suposto que estas (e os galegos) representaban sempre o polo positivo desa oposición: eran superiores, europeos, progresivos, valentes, civilizados, bariles, libres.. (Máiz, 1984: 273-274).

\footnotetext{
${ }^{8}$ Estas características -melancolía, tristeza, imaxinación, espiritualidade...-foran aplicadas ós galos/franceses por autores franceses (Michelet, irmáns Thierry, Renan) para establecer unha oposición cos xermanos/alemáns (ós que aqueles consideraban prosaicos, materialistas e brutáns), dentro dun contexto de rivalidade política crecente entre os dous estados (Chapman, 1992). Posteriormente foron adoptadas por autores británicos (por exemplo Mathew Arnold) para caracterizar ós irlandeses, galeses e escoceses (Curtis, 1968). Murguía seguía especialmente a Renan (que falaba dos seus compatriotas bretóns) na súa caracterización, aínda que non se facía partícipe doutras opinións de Renan verbo dos celtas (sobre todo aquela que os imaxinaba como unha raza pouco práctica e incapaz de auto-gobernarse; $c f$. Curtis, 1968).
}

"CUADERNOS DE ESTUDIOS GALLEGOS", Tomo XLVII, Fascículo 113, Santiago 2000. 
Os galegos -por pertenceren á raza celta e polos seus aportes de sangue suevo que viñeran reafirmar o elemento ario-incluíanse por dereito propio dentro das razas arianas, que como xa vimos eran as razas progresivas por natureza. As súas capacidades intelectuais eran excelentes e as súas potencialidades para a civilización e a modernización inmellorables. Como deixara dito Murguía, polemizando contra o pesimismo do Conde de Gobineau, a elas pertencía "el dominio de la tierra», de elas era o futuro. Evidentemente, os logros e as perspectivas das razas indo-europeas non podían deixar de manifestarse no pasado e no futuro do pobo galego por mor da súa orixe celto-ariana; orixe da cal «con tanta razón [os europeos] se muestran orgullosos» (Murguía, 1865: 6) . $^{9}$

Outro aspecto desa identidade racial era o cultural.

Tanto o idioma galego como as crenzas e os costumes, as formas de actuar e de pensar, ou as institucións propias (a organización parroquial, as pequenas explotacións, o sistema foral...) viñan determinadas pola orixe celta dos habitantes do país.

A raza celta impoñia un Volksgeist especial, un «xenio» ou «espírito» particular do pobo galego, e este «xenio» non facía senón reflectirse nas produccións culturais dese pobo -na lingua, nas crenzas, nas tradicións...-, dándolles vida e deixando nelas unha pegada indeleble e característica. En palabras do propio Murguía:

"Toda la vida, ya intima, ya exterior, se informa en las viejas tradiciones conservadas entre nosotros con pía y misteriosa constancia. No hay dentro de la religión, de las creencias, del gobierno, de la vida interior, cosa alguna que escape á la fatalidad de su origen, delatándose, haciéndose patente, dominando por entero en nuestro corazón y en cuanto nos rodea» (Murguía, 1888b: 112).

De aí o interese que podía ter para Murguía, e para outros autores cunha ideoloxía semellante á súa, o estudio da cultura popular galega -do folklore galego-, porque a través dela facíase posible penetrar no "xenio»

\footnotetext{
${ }^{9}$ En aberta contradicción con esa celticidade invocada unha e outra vez como definidora do carácter galego, Murguía parecía suxerir en ocasións a existencia dunha mestura de caracteres celtas e latinos para dar conta da especial psicoloxía do pobo galego que el ás veces concibía como unha combinación entre a melancolía e o sentimento celtas e o «espíritu práctico» do romano (Murguía, 1901: 21-22).
}

"CUADERNOS DE ESTUdIOS GALLEGOS", Tomo XLVII, Fascículo 113, Santiago 2000. 
da raza e descubrir os fíos que movían a alma de Galicia (Murguía, 1881): o apego pola relixión e o respecto polos mortos representados na relixiosidade popular e en tradicións como a da Compaña; o naturalismo ariano reflectido nos testemuños de culto ós astros, ás augas ou ás árbores; o sentimento e a poesía presentes na literatura popular... Todo isto pretendía atopar investigando as tradicións galegas. Era unha maneira de reafirmar a celticidade do pobo galego e, xa que logo, a súa personalidade diferenciada.

Fronte a outros autores anteriores ou coetáneos que falaban das influencias doutros pobos -gregos, fenicios...-representadas nos costumes e crenzas galegas, Murguía facía derivar todas elas do fondo celta-ariano que animaba continuamente a vida dos galegos, e que constituía esa «fatalidade» de orixe que os facía permanecer fieles ó «espírito» e ás tendencias da súa raza.

En verdade que lendo algunha das páxinas consagradas ás tradicións galegas no seu libro Galicia tense a impresión de que Murguía vía nos montañeses galegos unha especie de arios primitivos que por un instinto racial realizaban aquelas cerimonias que xa practicaran os seus devanceiros pagáns: rendéndolle culto ó Sol, realizando ofrendas ó lume, pregando a protección da Aurora...

Pero se o determinismo racial no caso das razas inferiores tiña efectos negativos -os pobos inferiores non podían escapar das limitacións que lles impoñía a súa constitución racial-, no caso galego, e no doutros pobos de liñaxe xenuinamente ariana, a raza non era un atranco, senón unha vantaxe. Pois se por unha banda se podía falar do "eterno modo de ser» dos galegos (Murguía, 1888b: 117), e Murguía podía dicir que «nada ha cambiado entre nosotros» (ibid: 117); pola outra deixaba ben claro que a celta non era unha raza estancada e estéril como os semitas ou as razas de cor, "al contrario, como raza fecunda y vivaz, todo lo saca de un fondo propio, tanto en el orden moral como en el social y político» (ibid: 117). O que era tanto como afirmar que os galegos, aínda conservando o que lles era propio, non eran escravos do seu pasado e das súas inclinacións; que, como raza progresiva, podían (debían) mellorar continuamente por si propios, adoptando incluso - como foran facendo a través da súa historia- elementos alleos (romanización, cristianismo, distintas reformas económicas, políticas e sociais...), pero sempre incorporándoos e adaptándoos á súa peculiar forma de ser (e neste punto incluso Murguía podía avogar

"CUADERNOS DE ESTUDIOS GALLEGOS", Tomo XLVII, Fascículo 113, Santiago 2000. 
pola erradicación, para dar paso ó progreso, dunha institución de orixe celta como eran os foros; $c f$. Máiz, 1984).

Así era a identidade racial galega: á vez impoñendo unha fidelidade instintiva á tradición, pero tamén garantindo o pulo modernizadore progresivo propio das razas superiores. Estas eran as consecuencias máis importantes que para a súa definición implicaban os postulados raciais que se comentaron máis arriba.

Polo demais, esta identificación raza/Volksgeist/cultura/lingua entroncábao co pensamento antropolóxico alemán e especialmente coas definicións organicistas da nación -malia a que Murguía incluíse tamén elementos voluntaristas na súa definición da nación galega (aínda que estes ficasen nun segundo plano en relación ós primeiros; $c f$. Máiz, 1984).

Verbo disto, Ramón Máiz xa ten demostrado a grande importancia que a idea de raza tiña para Murguía á hora de fundamentar a nacionalidade galega (Máiz, 1984: 275-278). En primeiro lugar, como xa vimos ata aquí, creaba unha identidade propiamente galega, á vez que insería esa identidade dentro das razas arianas (con todo o que iso implicaba de positivo). En segundo lugar, fronte a esta identidade galega situábase o «outro», o castelán-andaluz que representaba o polo oposto das virtudes arianas, e contra o que se dirixían todas as acusacións, e a quen se atribuían todos os males do país, causados polo despotismo «semítico» do estado español centralista. Esa identidade común favorecía a unidade de todos os galegos, que se sentían membros dunha mesma raza, cunhas mesmas características, idéntico pasado e idéntico destino; co que as diferencias reais que existían entre eles (de clase, de ideoloxía, de educación...) debían ficar aparte, esvaídas por esa solidariedade racial. Ó chegar a este punto Murguía non resolvía o dilema que el mesmo se creara ó destacar, á parte da maioría da poboación galega de raza celta, aqueles grupos illados e minoritarios de ascendencia non-celta (fenicia, grega ou romana -só dos suevos dixera que se fusionaran completamente coa poboación autóctona) que descubrira coas súas «dotes» de tipólogo racial. Porque, se o pobo galego estaba caracterizado por ser de raza celta, e se esta determinaba a súa personalidade propia ¿daquela podíanse considerar «galegos» as persoas descendentes de xentes non-celtas? ¿presentaban tamén estas eses trazos particulares dos galegos que viñan determinados pola súa celticidade (algo que sería imposible, de seguir literalmente Murguía os seus presupostos de inmutabilidade racial)? O noso autor deixaba sen resposta 
estes interrogantes... quizais atrapado nunha calella sen saída á que o levaran os seus postulados raciais. O certo é que cando falaba do pobo galego facíao sempre dando por sentado a celticidade de todos os seus compoñentes, sen ter en conta posibles excepcións raciais -e isto incluíndo os supostos descendentes dos pobos semitas asentados noutrora en Galicia (fenicios, cartexineses ou xudeos), por máis que no seu imaxinario racial os semitas aparecesen como a antítese dos arios/galegos. Quizais nesta reticencia a facer distincións raciais dentro da propia Galicia si que se reflicta a súa ideoloxía liberal e se poñan de manifesto os elementos voluntaristas da súa definición nacionalitaria (sen contar que iso provocaría unha grave disxunción no seo mesmo da nación -e para os seus fins era máis útil transportar a retórica do antagonismo racial fóra das nosas fronteiras).

Finalmente esa oposición entre os galegos, arios e superiores, e os casteláns, semitas e inferiores, daba azos ás reivindicacións rexionalistas descentralizadoras de Murguía, razoando que non era xusto que un pobo superior -o galego- se vise sometido ó dominio por parte doutro que lle era inferior -os casteláns (por máis que Murguía, sempre tan convencido das elevadas cualidades dunha raza superior, non explicase como era posible que esta puidese ser sometida por xentes inferiores).

Xa que logo a idea de raza, con todas as súas implicacións e ambigüidades, tiña un papel central no pensamento de Murguía, tanto nas súas (non moi habituais) reflexións antropolóxicas, como na súa definición da identidade galega e na fundamentación nacionalitaria.

\section{CULTURA}

\section{Definicións}

Como acontecía no caso da raza, o pensamento de Murguía sobre o fenómeno cultural era asistemático. En ningún momento daba unha definición de «cultura» ou de «civilización» -termos estes que en xeral empregaba indistintamente. Tampouco atopamos unha reflexión sobre o que estes termos, eses feitos culturais, puidesen significar para el e a respecto doutros aspectos do seu pensamento (por exemplo en relación á súa teorización verbo da nación ou da identidade galega). O que se poida averiguar sobre isto ten que facerse a través de breves referencias, de simples 
retazos de opinións -case sempre de carácter secundario- que non sempre permiten unha compresión clara das súas opinións ó respecto (fenómeno, por outra banda, frecuente no que atinxe a todo o pensamento antropolóxico na Galicia decimonónica; $c f$. Pereira González, no prelo).

Comezemos pola definición de «cultura».

Aínda que variando dun autor a outro e dunha «escola» a outra, o termo «cultura» na literatura antropolóxica actual fai referencia á práctica totalidade das distintas manifestacións da existencia dun grupo humano, das súas pautas de comportamento e de pensamento: organización social, economía, tecnoloxía, relixión e visión do mundo, normas de actuación, etc. Ademais, a actual definición de «cultura» está animada por presupostos relativistas, historicistas, holísticos e de determinismo cultural (Stocking, 1968).

Comparando con esta definición actual as vagas referencias ó termo que se atopan esparexadas polos escritos de Murguía é posible un mellor achegamento ó seu pensamento a este respecto.

«Cultura» tiña para Murguía dous significados principais; significados estreitamente vencellados entre si, ata o extremo de que en ocasións é moi difícil determinar cal era o que se lle estaba a dar nunha expresión concreta (e incluso a miúdo non é doado establecermos se o propio autor pretendía esa diferenciación). Só algúns matices de expresión fan posible -poucas veces- esa distinción.

En primeiro lugar, «cultura» viña de significar o grao de ilustración, de excelencia intelectual acadado por un pobo, facendo ademais fincapé nas súas expresións máis elevadas; ilustración que se via reflectida principalmente a través das súas artes, da súa literatura, da súa producción intelectual, da súa moral, etc. Do mesmo xeito que no século XVI a palabra «cultura» (que antes tiña o significado literal -tirado da linguaxe agraria- de «cultivo») comezara a acadar o sentido metafórico de «cultivo persoal»-desenvolvemento do intelecto e das virtudes de cada individuo-, Murguía empregará esa palabra en moitas ocasións para indicar o grao de «cultivo» ou de ilustración dunha sociedade determinada. É frecuente tamén que use, cun sentido idéntico, o termo «civilización».

De aí, por exemplo, que faga referencia a «el grado de cultura y riqueza á que había llegado [Ribadavia] en los comienzos del siglo XIII» (Murguía, 1888b: 836); que fale dos mosteiros galegos como «centro y hogar de la cultura de su edad en nuestro país» (ibid: 1.137); ou que considere a poesía como a primeira manifestación da cultura dun país.

"CUADERNOS DE ESTUDIOS GALLEGOS", Tomo XLVII, Fascículo 113, Santiago 2000. 
E estreitamente relacionado con este estaba o outro significado que a esa verba lle daba Murguía, e que quizais se poida considerar como o máis utilizado polo autor: a «cultura» considerada como aquela acumulación de artes, literatura, ciencias, leis, moral, etc., manifestacións todas elas das cualidades espirituais, intelectuais, artísticas, técnicas e políticas. En definitiva, os testemuños do desenvolvemento intelectual que desfrutaba unha sociedade dada.

Precisamente era este o sentido que tiña esa palabra nesa súa «pseudodefinición» de «cultura» (o máis perto que estivo Murguía de explicitar o seu significado) que atopabamos no terceiro tomo da Historia de Galicia (a cita en cuestión facía referencia ós descoñecidos eruditos da Galicia medieval):

«Se ignoran los nombres de los que acá trajeron el amor á la ciencia, á la poesía, al arte, en una palabra á la cultura de su tiempo» (Murguía, 1888a: 31 . O subliñado é meu).

Con este mesmo sentido había que entender tamén as referencias a "nuestra cultura nacional» presente nos mosteiros galegos do Medievo (Murguía, 1888b: 433); á "antiga cultura» (a cultura greco-romana - é dicir, a arte, literatura, filosofía, etc. da Grecia e da Roma clásicas); ou á decadente «cultura árabe» (Murguía, 1888a: 26).

É dicir, que se o primeiro significado se refería a esa ilustración nun sentido abstracto (o nivel de educación ou de excelencia intelectual presente en cada época ou en cada sociedade), o segundo centrábase nas manifestacións concretas da creatividade humana a través das cales se medía precisamente o grao de «cultivo» intelectual adquirido por un pobo. En calquera dos dous casos, sen embargo, a énfase estaba posta nos logros e no refinamento acadado por unha sociedade.

No seu sentido principal, e a diferencia das definicións actuais, a cultura non era para el o conxunto total de prácticas, de crenzas e de produccións dun grupo humano, independentemente do maior ou menor grao de complexidade e de alcance. En troques, e fixándonos nas implicacións que se podían enxergar a través do seu emprego do termo, «cultura» víase como aquelas manifestacións literarias, artísticas ou intelectuais producto do espírito humano. Era posible imaxinar unha escala xerárquica que marcase os distintos chanzos do desenvolvemento «cultural», dende os rudi- 
mentos da arte e do pensamento ata as súas expresións máis perfeccionadas. Pero a verdadeira cultura, a plena cultura, eran as obras de arte, as obras mestras da literatura ou da filosofía, os logros da ciencia... cousas que só se encontraba entre uns poucos pobos verdadeiramente ilustrados, que elevaran a súa creatividade ata cotas dificilmente superables; de aí as súas múltiples referencias a esa xerarquía cultural, indicada mediante expresións como "mayor grado de cultura», "refinada cultura», "cultura superior», ou "primitiva cultura»...

Neste sentido, «cultura» facíase sinónimo de «civilización» (co significado de elevada ilustración, pero tamén de xerarquías no nivel de ilustración), e ó longo dos escritos de Murguía os dous termos serán practicamente intercambiables, sen que entre eles se poidan atopar diferencias de significado ou de matiz.

Só nalgunhas ocasións a palabra «cultura» semellaba adquirir un significado un tanto diferente, cuns matices que xa non se centraban tanto no grao de ilustración e na representación do mesmo, senón que o termo parecía facer referencia ó conxunto de normas, de crenzas, de valores e de prácticas dunha sociedade; é dicir, que semellaba adquirir un significado holístico (¿e relativista?) que estaba máis perto da definición actual. Debido á falla de definición do pensamento de Murguía nestes aspectos non é posible afirmar isto con moita certeza. Pero afirmacións súas que falaban dunha comunidade de "cultura» e de «sentimientos públicos» entre señores e servos na Galicia medieval (Murguía, 1888a: 23), semellaban apuntar cara a esta dirección.

Mais, como norma xeral, cando Murguía se refería explicitamente ó conxunto de crenzas e de prácticas culturais dun pobo facíao con termos como «creencias», «usos», "costumbres» ou «tradiciones», e non co termo englobador de «cultura».

Expresións presentes a miúdo na súa obra, como «cultura celto-sueva», «cultura romana» ou «cultura fenicia», eran demasiado ambiguas e indeterminadas - a falla doutras indicacións no texto sobre o que se quería dicir con elas- como para decidir en principio cal era o seu verdadeiro significado. É posible que non vaiamos moi descamiñados ó pensarmos nunha combinación dos tres significados devanditos, quizais salientándose un ou outro aspecto segundo a intención de cada contexto (eséxese demasiado complexa e da que aquí só podo indicar a posibilidade).

"CUADERNOS DE ESTUDIOS GALLEGOS", Tomo XLVII, Fascículo 113, Santiago 2000. 
A mesma comparación pódese realizar verbo dos presupostos subxacentes na idea de cultura -hoxe en día marcada polo relativismo, o historicismo, o holismo e o determinismo cultural- para tentarmos clarexar o pensamento murguián.

Cando antes se falou do pensamento racial de Murguía, xa debeu de ficar claro que este non valoraba da mesma maneira a todos os grupos humanos, senón que establecía unha radical diferenciación entre o que el denominaba razas superiores e razas inferiores. As primeiras (as razas arianas e brancas) eran progresivas e intelixentes; as segundas (as razas semitas e as razas non brancas) eran atrasadas, estériles e decadentes. E as produccións culturais desas razas estaban en total consonancia con esta xerarquía racial: a civilización elevada, florecente, vizosa e enérxica dos pobos arios europeos contrastaba coa cultura insustancial, atrasada e estéril dos árabes/semitas, e co salvaxismo primitivo das tribos africanas -afastadas por sempre da historia humana. Unha idéntica actitude adoptaba a respecto dos idiomas humanos, cando falaba de linguas superiores (propias das razas superiores) e de linguas inferiores (propias das inferiores).

En todo caso, eran as distintas ponlas do tronco ariano -celtas, xermanos, gregos, latinos- as que obstentaban a primacía civilizadora e o monopolio case exclusivo dos logros culturais. E a «cultura nacional» galega, herdeira directa ou indirecta das razas e das civilizacións arianas, non podía senón beneficiarse e gabarse destas orixes.

Evidentemente, as xerarquías raciais e culturais que establecía Murguía non poden ser vistas como unha postura relativista, que considerase en igualdade de condicións a todos os pobos da terra e que concedese $o$ mesmo valor a todas as culturas, ó concibilas como adaptacións -todas elas igualmente válidas-ás distintas condicións de existencia e como un producto das circunstancias históricas. Neste punto Murguía situábase nas antípodas do concepto de cultura actual, a semellanza de tantos outros autores nunha época na que o relativismo cultural era un concepto e unha actitude extremadamente raras. E se de relativismo podemos falar na obra de Murguía, este ficaría limitado á representación positiva dunha cultura bárbara -a celta- e á súa valoración fronte á civilización greco-latina; ou mesmo expresaríase na simpatía ou complacencia con que ollaba a cultura popular galega -en oposición a outros contemporáneos seus que vían nas crenzas e tradicións populares simples «supersticións» que debían ser erradicadas canto antes en beneficio do progreso do país.

"CUADERNOS DE ESTUdIOS GALLEGOS", Tomo XLVII, Fascículo 113, Santiago 2000. 
Verbo doutro aspecto - da historia como configuradora das distintas realidades culturais-, Murguía semellaba, a primeira vista, compartir plenamente os presupostos historicistas do moderno concepto de cultura. En efecto, para el a historia era non só un instrumento que axudaba a comprender e a explicar o presente, ou un elemento máis na xustificación da nación galega, senón que tamén a imaxinaba como un factor configurador esencial da identidade galega. Porque era a través da historia como se ía formando un país e unha nacionalidade, e unha maneira de ser, de pensar e de actuar: comezando polos celtas e continuando polos feitos máis sobranceiros no devir de Galicia (romanización, cristianización, reino suevo, dominio visigodo, etc.), a historia e os seus acontecementos ían construíndo paseniño unha nación de seu. Por suposto que a súa era unha historia feita á medida dos seus intereses e presupostos -reinterpretando ou inventando o pasado, salientando aquilo que máis lle conviña e esquecendo o que non.

As afirmacións de fe historicista abundaban nos escritos de Murguía. Este tema xa foi estudiado por outros investigadores (Mato Domínguez, 1981; Máiz, 1984), polo que non necesito determe nel. Sen embargo si quero matizar algo a respecto do papel que en Murguía xogaba a historia como conformadora do presente e da identidade nacional. Porque, como xa ten salientado Ramón Máiz, a recurrencia ó mito celta por parte do escritor corunés (e de moitos outros historiadores galeguistas) tiña como resultado un rebaixamento da acción configuradora da historia (Máiz, 1997: 147-171). En efecto, en certo sentido Murguía estaba a negar esta acción cando lle daba tanta importancia a unha identidade racial celta inmutable e presente ó longo de toda a historia galega-identidade que se imaxinaba determinadora e limitadora (nun sentido positivo) das ideas e prácticas do pobo galego ${ }^{10}$. Dende o principio da historia de Galicia (que comezaba coa chegada dos celtas), dinos Murguía, as características raciais celtas estiveron sempre presentes -era esa "fatalidad de su origen» á que en ocasións se refería o autor; e nin a presencia de fenicios e gregos, nin a romanización subsecuente, nin ningún outro acontecemento histórico posterior, puideran erradicalas nin modificalas. A inmutabilidade racial era a

\footnotetext{
${ }^{10}$ "O mito céltico, en fin, fundamenta como natureza e identidade colectiva o que non é, dunha banda, senón intencionalidade político-ideolóxica nacionalista, e doutra, heteroxeneidade, dispersión e ruptura do tempo histórico dun cambiante fragmento espacio-temporal e social concreto» (Máiz, 1997: 153).
}

"CUADERNOS DE ESTUDIOS GALLEGOS", Tomo XLVII, Fascículo 113, Santiago 2000. 
garante da inmutabilidade no ser e no sentir de Galicia. Esta formulación axudaba á hora de reafirmar a radical orixinalidade da nación galega a respecto doutras rexións peninsulares, pero tiña como resultado establecer uns límites á acción da historia. O devir histórico non podía transformar aquilo que a raza gravara coa súa pegada indeleble no físico e nas mentes da poboación galega.

A historia como «mestra do presente» explicaba moitas cousas e deixaba esperanzas nun futuro mellor. Tamén fornecía novos elementos que eran asimilados e reformulados polo «xenio» da raza; pero -e a diferencia doutras formulacións clásicas sobre o Volksgeist- para Murguía non era a historia a creadora deste "xenio», senón que o Volksgeist dependía case exclusivamente das «excelencias» da raza.

En relación a isto, resulta agora pertinente dilucidar se o pensamento de Murguía verbo da cultura incluía tamén o determinismo cultural, é dicir se pensaba que os xeitos de pensar e de actuar das persoas estaban determinados unicamente, ou cando menos maioritariamente, pola súas normas e crenzas (pola súa "cultura», no sentido actual do termo) e non por outros factores alleos ós fenómenos culturais (como podían ser a raza ou o medio ambiente).

É certo que á hora de xustificar a nacionalidade galega, Murguía incluía -entre outros factores como eran a raza, a historia, a lingua, o territorio ou a vontade- as tradicións, as crenzas, os usos e os costumes propios de Galicia. Estes costumes e tradicións, asemade, daban conta da especial maneira de actuar dos galegos, e polo tanto formaban parte da súa identidade propia. E Murguía ás veces presentaba a estes actuando e pensando aínda como actuaran e pensaran os seus devanceiros, porque os galegos (ou cando menos a poboación rural) mantivéranse fieis ás tradicións dos seus pais e dos seus abós.

Así se lexitimaba a importancia que para Murguía tiña o estudio do folklore galego, das crenzas e dos costumes populares; estudio que era fundamental para coñecer o presente e o pasado do país, a súa identidade. E el mesmo quería dar exemplo, estudiando diversos aspectos da tradición, como a literatura popular.

Todo isto poden ser indicios da importancia que concedía ós factores culturais á hora de explicar o «ser» e o «vivir» dos galegos. Pero se lembramos todo o que se viu ata agora acerca do seu pensamento racial teriamos que admitir de contado que ese suposto determinismo cultural queda- 
ba moi esvaído -se non desaparecía totalmente- baixo o peso do determinismo racial que tantas veces estaba presente na súa obra: o pobo actuaba e pensaba como o fixeran os seus antergos non só porque quixese conservar as súas tradicións, por medio dun «simple» acto voluntario de conservadurismo, senón, e sobretodo, por mor dun involuntario sentido de fidelidade, por mor do seu «eterno modo de ser». A causa principal eran as tendencias innatas da raza. Os labregos galegos, ó conservaren intacta a súa pureza racial céltica, non podían deixar de comportarse como verdadeiros celtas.

O conservadurismo, o amor ós devanceiros, era precisamente un dos trazos constituíntes da identidade racial galega. Estas e outras características raciais -valentía, independencia, espiritualidade...-configuraban o inmutable Volksgeist galego, e este á súa vez reflectíase nas máis diversas manifestacións culturais (lendas, contos, cántigas, rituais, crenzas...), polo que estas en último termo eran un producto da constitución étnica da poboación, dunha tendencia racial (e non un producto continxente da historia). E iso explicaba o seu mantemento ó longo do tempo entre a meirande parte dos galegos, nomeadamente entre o campesiñado (ó que Murguía consideraba como o detentador das esencias da identidade galega).

Polo tanto, de termos que valorar o peso que no discurso antropolóxico murguián (e incluso no político) tiñan, respectivamente, os factores raciais e culturais, deberiamos recoñecer unha clara primacía dos primeiros, ata o punto de que eran estes os que chegaban a determinar os segundos.

Finalmente, o último presuposto do moderno concepto de cultura -o enfoque holista- tampouco se vía moi representado na obra de Murguía. Sendo os principais obxectivos do seu labor como historiador demostrar as orixes célticas de Galicia, a caracterización do país como nacionalidade, e o trazar as vicisitudes polas que pasara Galicia na constante procura da súa autonomía, estas angueiras deixábanlle pouco vagar para tratar polo miúdo os xeitos de vida e de pensamento de cada época histórica.

Esta carencia dun enfoque holístico víase con meirande claridade no seu tratamento da cultura popular galega. Entón a súa única preocupación era a de demostrar a orixe celta das diversas crenzas e costumes, de modo que esta demostración servise de apoio ás súas teses celtistas. A semellanza dos evolucionistas decimonónicos (por máis que el partise de presupostos diferentes), Murguía tiraba do seu contexto cultural certas crenza e 
prácticas que, analizadas como se fosen supervivencias de antigas épocas e comparadas con certas mitoloxías de xínea ariana, servíanlle para reafirmar a tese da celticidade de Galicia. Non lle interesaba presentar unha panorámica sincrónica da cultura popular para tentar abranxela como un todo artellado, coas súas coherencias, equilibrios e tensións, e buscar comprender como esas crenzas e prácticas se inserían e se explicaban dentro da vida cotiá dos actores das mesmas -seguindo un enfoque «funcionalista» emprendido xa por outros autores galegos contemporáneos seus (Rodríguez Campos, 1991).

En Murguía, xa que logo, primaba un estudio fragmentario e diacrónico dese folklore, collendo as partes del que máis lle interesaban (ou que máis lle conviñan) para presentalas como reliquias doutros tempos e trazar a súa orixe ata fontes célticas ou arianas. De aí que se centrase sobre todo nas lendas e na chamada «mitoloxía popular» («culto»á natureza, tradicións sobre os mouros ou sobre a Compaña, etc.), nas que vía continuamente pegadas das antigas relixións dos pobos indo-europeos.

\section{Enfoques}

Para rematar con esta análise sucinta do concepto de cultura en Murguía quería ampliar un tanto a perspectiva, e non limitarme unicamente a determinar cales eran para o escritor coruñés os significados posibles do termo e a comparalos co moderno concepto de cultura. En concreto pretendo no presente apartado ver cales eran as súas opinións acerca doutras cuestións antropolóxicas que constituiron importantes temas de investigación, discusión e reflexión no mundo occidental durante todo o século XIX: cuestións como as orixes, natureza e desenvolvemento da cultura (no sentido actual do termo)... cuestións que, vencelladas como estaban a outras verbo da orixe da propia humanidade, sobardaban con moito o simple interese erudito e se convertían en obxecto de acalorados debates nos que estaban en xogo diferentes visións do mundo, coas súas consecuentes implicacións relixiosas, éticas, políticas e sociais.

Como acontecía no caso das ideas de raza e de cultura, o escrito por Murguía a este respecto foi pouco, e na súa obra ocupaba un lugar claramente secundario: algunhas das preguntas que por entón se consideraban máis importantes, así como as posibles respostas que daquela se daban a esas cuestións, non foron plantexadas ou respostadas por Murguía, ou só o fixo dun xeito tanxencial.

"CUADERNOS DE ESTUDIOS GALLEGOS", Tomo XLVII, Fascículo 113, Santiago 2000. 
De novo, non había que atribuir isto á ignorancia de Murguía sobre esas cuestións (a abundante bibliografía que citaba indica que era perfectamente consciente dos debates contemporáneos sobre estes e outros temas antropóloxicos). Tratábase simplemente dunha cuestión de prioridades: o seu interese por Galicia, por dotala dunha identidade e dunha historia propias (o que, como xa se viu, implicaba tamén o manexo de conceptos antropolóxicos como o de «raza»), chegaba a eclipsar outros temas que preocupaban a outros eruditos contemporáneos (orixe da humanidade, transformismo, evolución cultural...).

Sen embargo, malia a recoñecer estas prioridades, a obra de Murguía non estaba totalmente desprovista do interese contemporáneo polas cuestións antropolóxicas de carácter xeral. Aquí e acolá é posible albiscar conceptos, ideas ou referencias que remitían a teorías e debates coetáneos e que sinalaban a Murguía como un home do seu tempo. En ocasións eran ideas que constituían un marco xeral sobre as que se desenvolvían despois os temas do seu interese. Pero só en raras ocasións estas cuestións antropolóxicas xerais afectarán ó seu labor como historiador ou como teorizador da nación galega, marcando e determinando o seu labor posterior (ó estilo dos "paradigmas» definidos por Thomas Khun), e sen as cales sería imposible entender ou realizar este.

Decidín realizar esta análise final do pensamento antropolóxico de Murguía pondo as súas ideas en relación cos tres principais enfoques antropolóxicos existentes no século XIX (e que en maior ou menor medida se podían atopar tamén en Galicia): o enfoque tradicional ou «ortodoxo», o evolucionista, e a «tradición antropolóxica alemana» (Pereira González, no prelo). Cada un destes enfoques implicaba unha serie de preguntas e de respostas diferentes referentes ás cuestións das orixes da humanidade e da cultura, polo que pode resultar de grande interese saber con cal deles -se con algún- gardaban máis semellanzas as ideas de Murguía acerca deses temas; iso permitiranos coñecer un pouco mellor as influencias presentes no noso autor, así como as súas opinións e actitudes a respecto das principais teorías e liñas de investigación antropolóxicas da época.

Comezando en primeiro lugar polo enfoque tradicional ou «ortodoxo» -o maioritario na Galicia decimonónica-, Murguía compartía algúns dos seus postulados, pero tamén difería do mesmo nalgúns puntos fundamentais. Se ben rexeitaba o transformismo e a idea da orixe simia do ser hu-

"CUADERNOS DE ESTUdIOS GALLEGOS", Tomo XLVII, Fascículo 113, Santiago 2000. 
mano, e adoptaba (como xa vimos) unha postura monoxenista; porén estaba disposto a admitir unha grande antigüidade para a humanidade, aceptando as conclusións das investigacións prehistóricas do momento (Pereira González, 1996). Sen embargo el rexeitaba as evidencias do suposto Home Terciario $^{11}$ (daquela no centro dos debates arqueolóxicos), que de seren certas levaría a aparición do ser humano sobre a Terra a unha época tan lonxana como o final da Era Terciaria, moitos millóns de anos atrás. Con todo, a súa aceptación da grande antigüidade da humanidade sinalada pola arqueoloxía prehistórica - que aínda negando o Home Terciario era moi elevada, en comparación cos catro mil/seis mil anos admitidos pola ortodoxia- arredábao dos sectores que en Galicia defendían con máis fervor o relato bíblico tradicional (sacerdotes, algúns profesores da Universidade e dos institutos).

Murguía afastábase do enfoque tradicional noutras cuestións de meirande importancia. Este enfoque, procurando sempre a compatibilidade coa narración bíblica e a súa xustificación, falaba dunha primeira humanidade que recén colocada por Deus na Terra xa desfrutaba dunha civilización avanzada -vivindo en sociedade, adorando ó Deus «verdadeiro», habitando en pequenas aldeas e vivindo da agricultura e da gandería, con metalurxia, etc.- gracias ás ensinanzas dunha revelación divina inicial. Os posteriores pecados dos humanos, e os correspondentes castigos divinos (Diluvio Universal, Torre de Babel...) puxeran punto final a esa primeira e beatífica etapa, e como consecuencia deles unha boa parte da humanidade, afastada do seu primitivo lugar de orixe (o Próximo Oriente), fora caendo en todo tipo de «aberracións»: idolatría, paganismo, prostitución, canibalismo, etc. Unicamente a prometida chegada de Cristo e o espallamento da súa mensaxe puideron mudar as cousas, evitando a inevitable dexeneración consecuencia da desviación dos mandamentos divinos, e volvendo a unir a toda a humanidade baixo a palabra de Deus.

\footnotetext{
${ }^{11}$ A este respecto Murguía citaba expresamente as teorías de Gabriel de Mortillet sobre o Anthropopitheco do Terciario, o suposto elo entre os simios e os humanos. El dubidaba seriamente de que tal ser existise; e aínda no caso de se demostrar a súa existencia, Murguía poñía en dúbida que semellante ser puidese ser considerado humano. A humanidade, na súa opinión, só aparecera cando houbo seres - persoas- que vivían en sociedade, que se comunicaban a través dunha lingua e que posuían unhas normas de convivencia común e unhas ideas relixiosas (Murguía, 1888b).
}

"CUADERNOS DE ESTUdiOS GALLEGOS", Tomo XLVII, Fascículo 113, Santiago 2000. 
Murguía, sen atacar directamente a narración bíblica e sen adoptar unha postura polemizadora, eliminaba da súa historia todas as referencias bíblicas. Se nas anteriores historias de Galicia (ou na do seu contemporáneo Vicetto) o relato bíblico seguía a ser o marco de referencia fundamental a través da cronoloxía tradicional, das xenealoxías bíblicas ou da realidade do Diluvio e dunha revelación divina inicial, no primeiro tomo da Historia de Galicia (1865) de Murguía todo isto desaparecía de golpe, sendo substituído en troques por referencias -a dicir verdade un tanto vagas-á grande antigüidade da humanidade, ós celtas e a unha escura poboación pre-céltica de orixe finesa... para todo o cal a información arqueolóxica xogaba un papel fundamental (Pereira González, 1998). Asemade falaba dunha historia humana marcada polo progreso continuo, e non pola súa dexeneración.

Aínda que neste momento Murguía non se fixese eco dun discurso claramente oposto ó relato tradicional -como era o evolucionista-, si era de grande importancia que todas as referencias bíblicas desaparecesen da súa historia, o que indicaba que xa estaba a ser influído polas distintas teorías non «ortodoxas» que corrían daquela por Europa, especialmente as relacionadas coas investigacións prehistóricas. Por outra banda, resulta evidente que isto tiña que afectar ó seu xeito de concibir a historia e á súa maneira de escribila -ampliando a perspectiva temporal da mesma, dando máis importancia á información arqueolóxica, e mudando radicalmente o discurso sobre os primeiros poboadores do país. Todo iso facía que a súa imaxe da primitiva historia de Galicia se diferenciase en boa medida das anteriores (aínda admitindo unha certa continuidade con elas).

En obras posteriores (por exemplo en Galicia, publicada en 1888) daría mostras da súa familiaridade coa arqueoloxía prehistórica, e amosaría a aceptación dalgunhas das súas teorías e implicacións (entre elas a aceptación dunha longa prehistoria humana dividida en distintas épocas que representaban unha escala de avance crecente); aínda que en xeral non chegou a aplicalas a Galicia por mor do seu compromiso celtista, nin pretendeu tampouco facer delas o guieiro das súas propias investigacións (Pereira González, 1998).

O que me interesa salientar aquí é que a aceptación desas ideas -aínda que simplemente teórica e practicamente sen desenvolver en todas as súas implicacións- estaba levando a Murguía lonxe das versións máis «ortodoxas» do enfoque tradicional (que eran precisamente aquelas que predo-

"CUADERNOS DE ESTUDIOS GALLEGOS", Tomo XLVII, Fascículo 113, Santiago 2000. 
minaran ata entón en Galicia). Aceptando a grande antigüidade da humanidade, unha longa prehistoria, un estado de salvaxismo inicial (representado pola humanidade da Idade de Pedra), e o continuo progreso a partir dese salvaxismo (progreso representado polas diferentes etapas definidas pola arqueoloxía: Paleolítico, Neolítico, Idade do Bronce, Idade do Ferro), Murguía arredábase do primitivismo e do dexeneracionismo propios do relato tradicional, á vez que compartía, cando menos en aparencia, presupostos evolucionistas (isto verase un pouco máis adiante).

A súa confianza no progreso humano (polo menos no que se refería ás razas arianas) facía desaparecer as vellas explicacións dexeneracionistas. E isto afectaba incluso á súa imaxe da antiga historia de Galicia. O seguinte exemplo é ben significativo a este respecto. Todos os autores que, dende Verea y Aguiar ata Vicetto (e incluso o primeiro Leandro Saralegui y Medina), escribiran sobre os primeiros habitantes de Galicia -que resultaban ser case sempre os celtas-imaxinábanos posuidores dunha relixión «pura»-monoteísta e sen idolatrías, que consistía na adoración dun deus sen nome e sen imaxes nas clareiras dos bosques nas noites de lúa; relixión que consideraban herdeira directa daquela orixinariamente revelada por Deus a toda a humanidade. Só co paso do tempo e coa chegada doutros pobos a Galicia (fenicios, gregos, cartaxineses, romanos), esa primitiva relixión dos celtas fora «contaminándose» do paganismo dos visitantes, dexenerando ó facerse politeísta e idólatra. En Murguía, pola contra, xa non atoparemos esta explicación dexeneracionista, e nel xa non quedaba case ningunha pegada da «relixión patriarcal» dos celtas galaicos. El imaxinábaos cunhas crenzas relixiosas primitivas, totalmente politeístas e con grande influencia do naturalismo (adoración dos astros, augas, árbores...), de nidias raigames indo-europeas; tan só a celebración de rituais baixo o luar (información contida nas fontes clásicas) vencellaba a relixión dos celtas de Murguía coa imaxe que mantiñan os seus predecesores e coetáneos.

Sen embargo Murguía si semellaba compartir co relato tradicional o providencialismo, a idea de que era Deus quen, en última instancia, dirixía a historia humana. Non está moi claro como se deben interpretar as súas alusións ó control da historia por parte da Divina Providencia -se deben ser tomadas ó pe da letra ou se pola contra só se trataba dunha maneira de falar, basicamente alegórica, habitual por entón. Porén o que si se debe indicar é que as súas afirmacións providencialistas estaban re-

"CUADERNOS DE ESTUDIOS GALLEGOS", Tomo XLVII, Fascículo 113, Santiago 2000. 
feridas tan só a procesos xerais -o progreso xeral da humanidade estaba dirixido por Deus, era a divindade a que «garantira» ós arios o dominio do mundo, etc.-, namentres que á hora de explicar acontecementos particulares, como os que marcaban a historia de Galicia, el acodía a explicacións puramente humanas.

Se agora pasamos ó enfoque evolucionista, observaremos que a relación que con el mantiña Murguía era igualmente ambigua. Xa vimos que, se ben rexeitaba o evolucionismo biolóxico (cando menos a respecto do ser humano), si que aceptaba algúns dos postulados dun discurso evolucionista: antigüidade do ser humano, estado de salvaxismo inicial (anti-primitivismo), progreso continuo a través de diferentes etapas... aínda que estes postulados, é certo, non eran privativos unicamente dos evolucionistas.

Pero se analizamos máis polo miúdo as ideas de Murguía verbo do desenvolvemento da civilización, atoparemos que a pesar das coincidencias de partida cun enfoque evolucionista (ó admitir unha evolución xeral da humanidade, do máis primitivo ó máis civilizado -ou da Idade da Pedra ata a Era Industrial), o resto das opinións de Murguía afastábano bastante dunha posición nidiamente evolucionista (polo menos do discurso evolucionista máis frecuente no século XIX e nas primeiras décadas do XX).

O evolucionismo «clásico» era basicamente unilinear; concibía a toda a humanidade pasando polos mesmos estados culturais (que eran case idénticos en todas partes) a través dun continuo proceso progresivo ata acadar, de xeito case inevitable, o estado no que se atopaba a civilización occidental. Aínda que ata entón ese estado só fora acadado por uns poucos pobos (todos de raza aria e branca), na teoría agardábase que, tarde ou cedo, toda a humanidade chegase ó mesmo punto. A idea da unidade psíquica da humanidade (da que se falou máis arriba) era a garante desta confianza. Na teoría (aínda que na práctica se recoñecesen excepcións), o paso dun estado cultural a outro era de carácter evolutivo e endóxeno: cada grupo humano pasaba polas distintas etapas mediante un proceso interno de desenvolvemento propio (as causas dese proceso eran discutidas e variaban duns autores a outros -adaptación ó medio, progreso tecnolóxico, novas ideas...) e non a causa dun impulso dado por outros grupos humanos máis avanzados. Do mesmo xeito, as semellanzas culturais entre distintos pobos (ás veces moi arredados xeograficamente) explicá-

"CUADERNOS DE ESTUDIOS GALLEGOS", Tomo XLVII, Fascículo 113, Santiago 2000. 
banse facéndoos partícipes dun idéntico estado evolutivo. As explicacións difusionistas, tan frecuentes noutros enfoques antropolóxicos, eran eliminadas ou minimizadas.

As opinións e as asuncións de Murguía, tanto á hora de escribir a súa historia de Galicia como noutros asuntos máis xerais, viñan de feito a negar estes postulados evolucionistas. En primeiro lugar, se ben cría no progreso humano, non imaxinaba este dende unha perspectiva evolucionista, pois para el o progreso non era un proceso interno, evolutivo, senón que na meirande parte dos casos se debía a unha influencia exterior: un grupo humano acadaba unha civilización superior gracias ó influxo doutro grupo máis avanzado, a través dun proceso de difusión ou de invasión. Os seus escritos estaban cheos de explicacións invasionistas e difusionistas (Pereira González, 1996): a chegada dos celtas a Galicia, que supoñía a introducción do metal e da agricultura e a desaparición da primitiva poboación pre-céltica; o paso da Idade de Pedra á metalurxia en Centro Europa, como resultado das invasións arias; os aportes á cultura e á historia galegas por parte das sucesivas vagas de «invasores» (celtas, fenicios, gregos, romanos, suevos...), etc.

Murguía admitía unha evolución xeral da civilización. Pero esa evolución xeral, ese progreso, era un progreso descontinuo e non evolutivo, no que o desenvolvemento dunha sociedade particular se vía cortado ou impulsado polo contacto con outras xentes. Ademais, no entanto uns grupos eran responsables de todo o progreso humano, outros meramente seguían a corrente, ou ben ficaban parados no tempo. Esta visión do progreso cadraba ben coa súa visión da humanidade en termos de xerarquías rảciais: eran sobre todo as razas superiores -os pobos arios- as responsables dos adiantos da civilización, adiantos que mediante difusión ou (fundamentalmente) invasión se comunicaban ás razas inferiores (no caso de que estas puidesen «resistilos» ou facer uso deles). Non podía admitir que, por exemplo, os pobos africanos tivesen chegado (ou puidesen chegar algunha vez) polos seus propios medios a unha civilización como a occidental.

Murguía concibía os tempos prehistóricos basicamente a través do prisma interpretativo que lle fornecía a era de imperialismo na que estaba a vivir, no sentido de que, tanto hoxe como onte, foran os arios/brancos/ europeos os creadores da civilización e os encargados de exportala a outras rexións do globo (e no sentido da semellanza en canto ó triste destino que lles agardaba ós pobos sometidos).

"CUADERNOS DE eSTUdiOS GALLEGOS", Tomo XLVII, Fascículo 113, Santiago 2000. 
Como contrapartida, ese enfoque difusionista culminaba nunha xustificación do colonialismo ó presentalo como o portador das «luces» da civilización penetrando no corazón das tebras do salvaxismo.

Pero aínda había máis, porque Murguía ó rexeitar a idea dunha evolución unilinear universal negaba incluso o concepto de unidade psíquica da humanidade. Non podía admitir que nunha época moi antiga as razas arianas superiores estiveran no mesmo estado cultural cós africanos máis primitivos e inferiores. Cada raza ou grupo de razas debía seguir un camiño diferente que lles era propio e que non tiña comparación con outros. A crenza nunha xerarquía racial estaba, de novo, na base do seu rexeitamento dunha explicación plenamente evolucionista.

A frase seguinte (que estaba referida ós fenómenos relixiosos) reflectía ben estas opinións. Obsérvese que se ben recoñecía a realidade dunha evolución, ou progreso, cultural en termos xerais -esa «ley de la evolución»-, negaba porén a posibilidade dun mesmo proceso evolutivo aplicable a toda a humanidade:

«Pretende ahora la escuela evolucionista que la humanidad, en esta serie de conocimientos [as ideas relixiosas], pasó por una génesis igual para todos los hombres y para todas las razas. Llega hasta asegurar que si pudieramos leer en el cerebro de los animales superiores hallaríamos una mitología rudimentaria, y que si el antropoideo fuese capaz de elevarse á la idea de Dios, la concebiría á la manera que el primero de los hombres en el orden de la sucesión, y tal como al presente podría hacerlo un tasmanio á ser posible hallarle libre de todo pre-juicio. Es error fundamental hijo de los exclusivismos de todos los sistemas absolutos (...). La ley de la evolución, es en verdad tan exacta como de antiguo conocida; no quita ni pone, pero nadie dirá que las razas superiores, ni aún en su estado mental más rudimentario, concibieron y expresaron la idea de divinidad á la manera que las inferiores» (Murguía, 1888b: 140-141).

Os arios progresaban sen cesar, namentres que os africanos, os indios ou os australianos ficaban estancados na súa primitiva existencia e unicamente podían sair dela adoptando (se podían) a civilización ariana. O desexo de fondo era, manifestamente, o de defender a especificidade (e a superioridade) das razas arias (a celta incluída).

"CUADERNOS DE ESTUDIOS GALLEGOS", Tomo XLVII, Fascículo 113, Santiago 2000. 
Isto non só tiña consecuencias teóricas, senón que tamén afectaba á hora de facer historia e á hora de considerar a cultura popular galega - eses usos, costumes ou tradicións que conformaban o estudio do folklo$r e-$ nun marco máis amplo. Implicaba, primeiro, un rexeitamento da metodoloxía evolucionista básica -do chamado «método comparativo», polo cal se establecían paralelismos entre as crenzas e costumes de pobos e épocas diferentes con vistas a dilucidar estados culturais dentro do proceso evolutivo; e, en estreita relación con este rexeitamento, supoñía unha interpretación dos survivals (das «supervivencias» actuais de usos e crenzas primitivos) en clave anti-evolucionista e en termos historicistas, cando non raciais: eses survivals só se podían pór en relación con outras tradicións que pertencesen a pobos da mesma raza. Para coñecer as primeiras fases da relixión dos pobos arios europeos (neste caso, dos celtas galegos) non había que acudir ós exemplos de razas primitiva. Só se podía usar a lingüística indo-europea, as antigas mitoloxías arias e, sobre todo, a información etnográfica obtida entre os europeos actuais, nomeadamente entre o campesinado, descendentes directos dos antigos arios (como os galegos):

«No es por tanto buen método ir á buscar en los pueblos salvajes, pero que dentro de símismos llegaron al summum de sus conocimientos, lo que se halla mejor en el hombre solitario é ignorante de las razas europeas, el cual, aun viviendo vida intelectual rudimentaria, se presenta sin embargo á nuestros ojos superior en todo, al que suponen su equivalente» (Murguía, 1888b: 141).

Polo tanto, aínda que na teoría puidese haber certas coincidencias entre as opinións de Murguía e os postulados evolucionistas, á hora de desenvolver as súas ideas o escritor coruñés chegaba a implicacións que se contradicían fortemente co evolucionismo decimonónico, motivadas en boa parte polos seus prexuizos arianistas.

Queda por último analizar as posibles relacións entre Murguía e a «tradición antropolóxica alemana». Neste caso as coincidencias amosábanse máis importantes.

En primeiro lugar estaba a coincidencia na orientación xeral de Murguía e dos adherentes á «tradición antropolóxica alemana», co interese de ambos centrado no estudio de sociedades particulares, en clara oposición 
á orientación evolucionista de carácter universalista. En efecto, esta primaba un achegamento nomotético ó estudio dos fenómenos culturais, procurando en todo momento atopar as leis que rexían o comportamento humano, do mesmo xeito que era posible atopar as leis que estaban detrás dos fenómenos naturais, con vistas a trazar o devir universal da humanidade, dende a súa aparición na Terra ata a actualidade, e dilucidando pautas e regularidades, así como causas e consecuencias neste proceso xeral (Stocking, 1987). Neste sentido as culturas particulares só importaban na medida en que podían ser representativas dese devir universal, pero non eran interesantes por si mesmas.

Todo o contrario era o que postulaba a «tradición antropolóxica alemana»: cada sociedade particular era digna dun estudio detallado e único, que dese conta das súas peculiaridades e dos seus valores. O que importaba era a pluralidade de culturas, non as coincidencias procesuais. O que se salientaba era a diversidade humana, os casos particulares, e non o sometimento de todas as sociedades a un idéntico devir e a unhas mesmas leis. Esas leis quizais algún día poderían ser achadas, pero sempre despois de estudiar a historia e as particularidades de cada grupo humano (Bunzl, 1996).

A actitude e os obxectivos de Murguía implicaban tamén o estudio individualizado dun pobo -o pobo galego-, de xeito que se puidese determinar a súa formación, os elementos que o constituían, a súa historia, a súa identidade e o seu valor. Evidentemente o interese de Murguía non era neutral (supoñendo que unha actitude tal poida existir nalgún autor), pois todo isto estaba supeditado, en última instancia, á súa ideoloxía galeguista e a unhas reividicacións de auto-goberno para o país.

Sen embargo -e aquí hai unha diferencia importante-, a actitude relativista (pola que se consideraban igualmente válidas e valiosas todas as tradicións, crenzas e costumes... última consecuencia dese interese pola diversidade humana) que a miúdo se atopaba entre os autores alemáns -Wilhelm von Humboldt, Waitz, Bastian, Boas- non era precisamente o «forte» de Murguía, como xa se comprobou máis arriba.

Máis importancia tiña a adopción por parte de Murguía do concepto clave da «tradición antropolóxica alemana»: o concepto de Volksgeist, de «espírito» ou «xenio» do pobo (Bunzl, 1996). Segundo a devandita tradición, cada grupo humano posuía un Volksgeist único e irreductible que determinaba a personalidade, as crenzas, os valores e os comportamentos

"CUADERNOS DE ESTUDIOS GALLEGOS", Tomo XLVII, Fascículo 113, Santiago 2000. 
das persoas que o integraban. Ese "xenio» manifestábase a través dos seus usos e costumes, da súa lingua e das súas crenzas, do seu carácter...

En repetidas ocasións Murguía facía referencia ó «carácter» ou ó «xenio» galego, como xa vimos no apartado dedicado á raza. Tamén se indicaron xa as peculiaridades que presentaba o Volkgeist galego segundo Murguía, e como estas se reflectían en distintos aspectos da cultura popular galega, o que explicaba o seu interese no estudio do folklore como medio de reconstrucción do «espírito» do pobo galego. En todo isto seguía as teorías de autores alemáns, expostas xa dende Herder (Bunzl, 1996).

Porén Murguía dáballe ó concepto de Volksgeist unha orientación racial que este non posuía orixinariamente. Nun principio o Volksgeist considerábase o resultado dun conxunto de causas tanto internas (a especial percepción do mundo por parte de cada grupo humano) como externas (como eran a adaptación ó medio ou o contacto con outros pobos), e xa que logo podía mudar ó longo do tempo (Bunzl, 1996). Pola contra para Murguía, xa o vimos, ese «xenio» particular era algo unicamente interno, unha característica racial e inmutable, como ese «eterno modo de ser dos galegos». O Volksgeist para Murguía era pois unha consecuencia da configuración racial (e polo tanto estaba sometida a esta) e non unha entidade autónoma, e iso tiña as súas consecuencias á hora de definir a identidade galega (Máiz, 1984).

Outra coincidencia que compartían (aínda que igualmente matizable) era a orientación historicista. $\mathrm{O}$ interese polas sociedades particulares levaba a centrarse na súa historia, para coñecer as súas orixes e o seu desenvolvemento e como medio de explicar a súa situación actual. Por outra banda, na «tradición alemana» a historia de cada pobo adquiría unha importancia especial, ó ser precisamente ó longo da mesma que se ía configurando o Volksgeist; era a historia a que determinaba e daba conta, en última instancia, das peculiaridades de cada sociedade. Como xa vimos, isto tamén se podía atopar en Murguía, aínda que a súa énfase na inmutabilidade do factor racial diminuía un tanto os efectos dese historicismo.

Por último cómpre subliñar tamén que Murguía compartía coa «tradición antropolóxica alemana» a preferencia por explicacións difusionistas para dar conta dos cambios e das semellanzas culturais (Bunzl, 1996).

Pódese dicir que, malia a certas diferencias e matizacións, era esa tradición o enfoque antropolóxico co cal o pensamento de Murguía presentaba as coincidencias máis importantes. Tampouco pretendo afirmar, por-

"CUADERNOS DE ESTUDIOS GALLEGOS", Tomo XLVII, Fascículo 113, Santiago 2000. 
que sería excesivo, que Murguía fose un xenuino representante dese enfoque antropolóxico (en primeiro lugar pola falla de sistematización do seu pensamento; en segundo lugar polas propias matizacións que xa indiquei). Pero as coincidencias eran demasiado importantes como para pensar nunha simple casualidade. Máis ben habería que falar dunha influencia xeral desta tradición sobre Murguía, influencia transmitida a través de certos autores -como Herder ou os irmáns Humboldt, ós que citaba en ocasiónsque eran representativos (e ata certo punto fundadores) da mesma.

Sen dúbida eran os presupostos principais desa tradición -0 interese nas culturas particulares (e na propia cultura), a idea do Volksgeist, o historicismo- e as teorías sobre a raza transmitidas a través das obras de autores franceses (Edwards, Bérard,Amédée Thierry) e das teses arianistas (de Gobineau, Renan ou Pictet), as premisas que mellor se axeitaban ós propios obxectivos do noso autor. E iso pode explicar a súa adopción como postulados básicos do seu pensamento e das súas investigacións. Neste caso si que se trataba dunha influencia de grande importancia, pois estaba na base do seu achegamento á historia e da súa concepción da identidade galega.

Creacionismo, monoxenismo, grande antigüidade da humanidade, antiprimitivismo, crenza no progreso (descontinuo e non evolutivo), difusionismo e invasionismo, interese nas culturas particulares, concepto de Volksgeist, historicismo, xerarquías raciais e culturais... eran as ideas que, en grandes trazos, compoñían o seu pensamento antropolóxico, e que en ocasións tiñan importantes implicacións para o seu discurso histórico e político.

\section{CONCLUSIÓNS}

Hoxe en día moitas das ideas antropolóxicas de Murguía pódense considerar superadas -afortunadamente, se temos en conta especialmente as súas ideas acerca da raza.

Sen embargo neste artigo non quixen adoptar unha postura presentista que xulgase o pensamento antropolóxico de Murguía en termos da antropoloxía actual, sinalando os puntos nos que diferían entre si, os erros e as limitacións que dende unha perspectiva actual presentaban as súas opinións. Incluso a comparación establecida entre a(s) idea(s) de «cultura»

"CUADERNOS DE ESTUDIOS GALLEGOS", Tomo XLVII, Fascículo 113, Santiago 2000. 
sinalada(s) en Murguía e os presupostos actuais tiña como obxecto, simplemente, axudar a unha mellor compresión da primeira, e non o seu xulgamento. Unha postura tal, avaliando o seu pensamento cos parámetros do presente, sen dúbida non deixaría en moi bo lugar ó noso autor. Falariamos dos seus prexuízos etnocéntricos, da súa inxenuidade, da súa falla de datos empíricos ou do seu sometemento a obxectivos extra-científicos. E probablemente nos sentiriamos ledos de estarmos nunha situación moi diferente á súa, de termos a investigación científica como única (?) guía e obxectivo do noso traballo, ou do progreso dos nosos coñecementos.

Mais, por moito que esa conclusión nos chegase a satisfacer, penso que se queremos coñecer ben o pensamento antropolóxico de Murguía (así como outros aspectos do seu pensamento e da súa obra) deberemos deixar de lado ese presentismo e procurar situar e entender as súas opinións e as súas prácticas no contexto histórico ó que pertencían. Iso foi o que tentei facer nesta nova achega ó estudio do pensamento antropolóxico na Galicia decimonónica.

Quizais sexa útil considerar as «peculiaridades» de cada autor en termos dunha inter-acción entre os contextos social-político-ideolóxico-científico nos que vivían (que fornecían de posibilidades e de inquedanzas, das preguntas e das respostas posibles, de teorías e de prácticas) e os obxectivos que se marcaba cada un (que dependían en parte dos devanditos contextos e que asemade determinaban os intereses e as prioridades, os medios a empregar e os xeitos de usalos, as preguntas e as respostas).

Murguía inseríase nun contexto político e ideolóxico xeral caracterizado, entre outras cousas, polo agromar das reivindicacións nacionalistas en Europa, o apoxeo do capitalismo imperialista, o cuestionamento da narración bíblica e a crecente importancia das teorías raciais... Así mesmo, os distintos saberes existentes marcaban os seus límites epistemolóxicos e metodolóxicos. Todo o cal non podía deixar de influir na súa visión do mundo, no seu labor e nos seus anceios: desexo de autonomía para o seu país, establecemento de xerarquías raciais e desprecio polos pobos non europeos, favorecemento das teses invasionistas, creación dun novo marco cronolóxico e conceptual para a súa historia de Galicia, etc.

Pero ademais do contexto xeral é fundamental ter en conta os obxectivos, intereses e prioridades do autor.

O obxectivo «erudito «de Murguía era establecer unha identidade para Galicia -para o cal era preciso escribir a súa historia, estudiar o seu

"CUADERNOS DE ESTUDIOS GALLEGOS", Tomo XLVII, Fascículo 113, Santiago 2000. 
folklore, a súa literatura e a súa arte, definir o seu carácter e darlle unha nova identidade racial-, o que en última instancia debía servir para as súas reclamacións de autonomía política e cultural. Desta maneira, as preguntas antropolóxicas fundamentais que se facía eran: ¿quen somos os galegos? ¿que significan as diferencias e as semellanzas a respecto doutros pobos? ¿como podemos coñecer a nosa orixe e establecermos a nosa singularidade? E isto marcaba os intereses e os límites de Murguía.

Na procura de respostas acodía a unha ampla serie de disciplinas e de discursos, de teorías e de prácticas: a «historiografía» romántica, sobre todo francesa e británica; a tradición historiográfica galega (non só os seus predecesores máis inmediatos e primeiros forxadores do celtismo galego -Verea e Padín-, senón tamén ós autores dos séculos XVI, XVII e $\mathrm{XVIII)}$; as fontes clásicas sobre a antiga Gallaecia; a lingüística comparada, nomeadamente a que trataba coas linguas indo-europeas (e que fora a primeira responsable da creación do mito ario); a arqueoloxía prehistórica e protohistórica (para el tiña especial interese o estudio dos megalitos, que el consideraba monumentos puramente célticos); a «tradición antropolóxica alemana»; of folklore e o estudio comparativo das relixións, a través do cal procuraba interpretar a «mitoloxía popular» galega á luz da primitiva relixión ariana; as teorías raciais da época (especialmente de antropólogos franceses da primeira metade do século XIX), así como todo un amplo conxunto de representacións sobre o «outro» non-europeo herdadas de séculos anteriores pero reactualizadas segundo os novos contextos epistemolóxicos e de relacións político-económicas. Todo isto fornecíanlle dos elementos co que construir aquilo que se impuxera como tarefa. Pero tampouco se limitaba a ser unha simple «correa de transmisión» dos saberes do seu tempo, porque Murguía realizaba unha selección dos mesmos -das súas temáticas, teorías e técnicas- seguindo os seus intereses e as súas prioridades. Algúns exemplos desta selección xa os vimos antes, pero había outros.

Por exemplo, no aspecto arqueolóxico Murguía seguirá mantendo a orixe celta dos monumentos megalíticos, cando a meirande parte dos investigadores máis reputados xa abandonaran esa explicación a prol de teorías máis sofisticadas. E o mesmo cabe dicir do seu apoio á teoría sobre a poboación pre-céltica de orixe finesa, teoría invalidada nas últimas décadas do século XIX, pero que aínda seguía a empregar Murguía para dar 
sentido á súa imaxe da prehistoria europea (que tendía a ter en conta unicamente o elemento céltico).

Igualmente, os seus obxectivos e compromisos tamén se reflectían nas súas ideas raciais. Non pode ser unha casualidade a súa elección dos presupostos e das teorías de Edwards verbo da inmutabilidade das razas; pola contra, eran estes uns firmes alicerces nos que apoiar as pretensións de Murguía sobre a singularidade dos galegos. Ademais os seus métodos impresionistas de clasificación racial permitían a Murguía unha rápida e satisfactoria determinación do substrato racial do país (lembremos que se cría capaz -como o propio Edwards- de distinguir a simple vista a raza á que pertencía practicamente cada habitante de Galicia). Aínda que o dogma racial se mantivo ata ben entrada a presente centuria, refinamentos técnicos e teóricos realizados durante a segunda metade do XIX fixeran imposible manter a confianza nas clasificacións raciais impresionistas de décadas antes. Non obstante as ideas raciais de Murguía mantivéronse tan inmutables como a súa raza galega, precisamente porque lle seguían sendo útiles.

Poderíase dicir que a adopción do factor racial como un elemento decisivo á hora de configurar o seu discurso galeguista tivo importantes consecuencias non só para o seu pensamento político ou para o seu labor como historiador (como xa demostrou Ramón Máiz), senón tamén para o seu pensamento antropolóxico. Pois este peso das explicacións raciais en Murguía influiu grandemente nas súas opinións sobre a identidade galega ou sobre as posibles relacións do pobo galego con outros pobos (con outros países celtas ou cos casteláns/semitas), e determinaba tamén en boa medida a visión que tiña sobre a propia humanidade e a súa historia (rexeitando, por exemplo, algunhas das ideas básicas do evolucionismo). Ademais chegaba a modificar certos contextos nos que se insería, como por exemplo aqueles presupostos da «tradición antropolóxica alemana» por el adoptados; á vez que tendía a interpretar os feitos culturais como meros «apéndices» da peculiar composición racial de cada grupo humano.

"CUADERNOS DE ESTUDIOS GALLEGOS", Tomo XLVII, Fascículo 113, Santiago 2000. 


\section{BIBLIOGRAFÍA}

BANTON, M. (1979): A Ideia de Raça. Lisboa. Edições 70 [orixinal: The Idea of Race, 1977].

BERAMENDI, J. G. (1982): «La Galicia de Murguía» en MURGUÍA, M. M.: Galicia [edición facsímil] Vigo. Xerais; p. I-XLVIII. - (1998): Manuel Murguía. Santiago de Compostela. Xunta de Galicia.

BLANCKAERT, C. (1988): «On the Origins of French Ethnology. William Edwards and the Doctrine of Race» en STOCKING, G. W. Jr. (ed.): Bones, Bodies, Behavior. Essays on Biological Anthropology. Madison. The University of Wisconsin Press; p. 18-55.

- (1989): «L'Indice Céphalique et l'Ethnogénie Européenne: A. Retzius, P. Broca, F. Pruner-Bey (1840-1870)» en BLANCKAERT, C., A. DUCROS e J. J. HUBLIN (eds.): Histoire de l'Anthropologie: hommes, idées, moments en Bulletins et Mémoires de la Sociéte d'Anthropologie de París, n.s., t. I, no 3-4; p. 165-202.

BUNZL, M. (1996): «Franz Boas and the Humboldtian Tradition. From Volksgeist and Nationalcharakter to an Anthropological Concept of Culture» en STOCKING, G. W. Jr. (ed.): Volksgeist as Method and Ethic. Essays on Boasian Ethnography and the German Anthropological Tradition. Madison. The University of Wisconsin Press; p. 17-78.

CURTIS, L. P. (1968): Anglo-Saxons and Celts. A Study of Anti-Irish Prejudice in Victorian England. Connecticut. University os Bridgeport.

CHAPMAN, M. (1992): The Celts. The Construction of a Myth. London. The MacMillan Press.

DIETLER, M. (1994): “' 'Our Ancestors the Gauls': Archaeology, Ethnic Nationalism and the Manipulation of Celtic Identity in Modern Europe» en American Anthropology, 96 (3); p. 584-605.

FOUCAULT, M. (1992): Genealogía del Racismo. De la guerra de las razas al racismo de Estado. Madrid. Las Ediciones de la Piqueta.

"CUADERNOS DE ESTUDIOS GALLEGOS", Tomo XLVII, Fascículo 113, Santiago 2000. 
HALL, E. (1989): Inventing the Barbarian. Greek Self-Definition through Tragedy. Oxford. Clarendon Press.

HANNAFORD, I. (1996): Race. The History of an Idea in the West. Baltimore and London. The Johns Hopkins University Press.

MÁIZ, R. (1984): O Rexionalismo Galego. Organización e Ideoloxía (1886-1907). Sada. Ediciós do Castro.

- (1997): «A función político-ideolóxica da Historia no discurso do nacionalismo galego» en MÁIZ, R.: A Idea de Nación. Vigo. Xerais; p. 147-171.

MATO DOMÍNGUEZ, J. A. (1981): Historiografia y Nacionalismo. La Construcción histórica de Galicia por los historiadores del siglo XIX $y$ primer tercio del $X X$. Tese de Licenciatura inédita. Santiago. Universidade de Santiago de Compostela.

MURGUíA, M. M. (1865): Historia de Galicia. Primer Tomo. Lugo.

- (1866): Historia de Galicia. Segundo Tomo. Lugo.

- (1881): «El Folklore Gallego» en La Ilustración Gallega y Asturia$n a$, tomo III, $\mathrm{n}^{\circ} 30: 352-353$.

- (1888a): Historia de Galicia. Tercer Tomo. A Coruña.

- (1888b): Galicia. Sus monumentos y artes. Su literatura e historia. Barcelona.

- (1889): El regionalismo gallego. Ligeras observaciones por... al discurso leído por el señor D. Antonio Sánchez Moguel en su recepción en la Real Academia de la Historia, de Madrid, el 8 de diciembre de 1888. La Habana.

- (1891a): Historia de Galicia. Tomo IV. A Coruña.

- (1891b): «Juegos Florales de Galicia celebrados por primera vez en la ciudad de Tuy el día 24 de junio de 1891 . Discurso d'o presidente Don....» en La Patria Gallega, $\mathrm{n}^{\circ}$ 7-8.

- (1901): Historia de Galicia. Primer Tomo. $2^{\mathrm{a}}$ edición. A Coruña.

OLENDER, M. (1989): Les Langues du Paradise. Aryens et Sémites: une couple providentiel. París. Gallimard.

"CUADERNOS DE ESTUDIOS GALLEGOS", Tomo XLVII, Fascículo 113, Santiago 2000 
OTERO, R. (1867): Galicia Médica. Apuntes para servir al estudio de la Geografía Médica de Galicia. Santiago.

PEREIRA GONZÁLEZ, F. (1996): Contribución á historia da arqueoloxía en Galicia: as opinións sobre a humanidade primitiva e a información arqueolóxica na Galicia do século XIX. Tese de Licenciatura inédita. Santiago. Universidade de Santiago de Compostela.

- (1998): O Emprego da Información Arqueolóxica en Galicia: 18001922. II Premio de Investigación. 1997 «Xesús Ferro Couselo». Concello de Valga.

- (no prelo): «O PensamentoAntropolóxico na Galicia do século XIX: Problemas e Perspectivas» en Gallaecia ${ }^{\circ} 18$.

POLIAKOV, L. (1971): Le Mythe Aryen. París. Calmann-Lévy.

RISCO, V. (1976) [1934]: Manuel Murguía. Vigo. Galaxia.

RODRÍGUEZ CAMPOS, J. (1991): «La Etnografía clásica de Galicia: ideas y proyectos» en PRAT, J., U. MARTÍNEZ, J. CONTRERAS e I. MORENO (eds.): Antropología de los Pueblos de España. Madrid. Taurus Ediciones; p. 99-111.

SAID, E. W. (1990): Orientalismo. Madrid. Libertarias [orixinal: Orientalism, 1978]

STOCKING, G. W. Jr. (1968): Race, Culture and Evolution. Essays in the History of Anthropology. Chicago. The University of Chicago Press [2 $2^{a}$ edición, 1982].

- (1987): Victorian Anthropology. New York. Free Press.

VELASCO SOUTO, C. F. (1998): «Murguía historiador» en Volver a Murguía, Cadernos «A Nosa Cultura» $\mathrm{n}^{\circ}$ 19. Vigo. A Nosa Terra: 18-23.

"CUADERNOS DE ESTUdIOS GALLEGOS", Tomo XLVII, Fascículo 113, Santiago 2000. 